Atmos. Chem. Phys., 13, 8719-8738, 2013

www.atmos-chem-phys.net/13/8719/2013/

doi:10.5194/acp-13-8719-2013

(C) Author(s) 2013. CC Attribution 3.0 License.

\title{
Light-absorbing carbon in Europe - measurement and modelling, with a focus on residential wood combustion emissions
}

\author{
J. Genberg ${ }^{1}$, H. A. C. Denier van der Gon ${ }^{2}$, D. Simpson ${ }^{3,4}$, E. Swietlicki ${ }^{1}$, H. Areskoug ${ }^{5}$, D. Beddows ${ }^{6}$, D. Ceburnis ${ }^{7}$, \\ M. Fiebig ${ }^{8}$, H. C. Hansson ${ }^{5}$, R. M. Harrison ${ }^{6,9}$, S. G. Jennings ${ }^{7}$, S. Saarikoski ${ }^{10}$, G. Spindler ${ }^{11}$, A. J. H. Visschedijk ${ }^{2}$, \\ A. Wiedensohler ${ }^{11}$, K. E. Yttri ${ }^{8}$, and R. Bergström ${ }^{12,13}$ \\ ${ }^{1}$ Division of Nuclear Physics, Department of Physics, Lund University, Lund, Sweden \\ ${ }^{2}$ TNO Netherlands Organisation for Applied Scientific Research, Utrecht, the Netherlands \\ ${ }^{3}$ EMEP MSC-W, Norwegian Meteorological Institute, Oslo, Norway \\ ${ }^{4}$ Dept. Earth \& Space Sciences, Chalmers Univ. Technology, Gothenburg, Sweden \\ ${ }^{5}$ Department of Applied Environmental Science (ITM), Stockholm University, Stockholm, Sweden \\ ${ }^{6}$ National Centre for Atmospheric Science, Division of Environmental Health \& Risk Management, School of Geography, \\ Earth \& Environmental Sciences, University of Birmingham, Edgbaston, Birmingham B15 2TT, UK \\ ${ }^{7}$ School of Physics \& Centre for Climate and Air Pollution Studies, Ryan Institute, National University of Ireland Galway, \\ Galway, Ireland \\ ${ }^{8}$ NILU, Norwegian Institute for Air Research, Kjeller, Norway \\ ${ }^{9}$ Department of Environmental Sciences/Center of Excellence in Environmental Studies, King Abdulaziz University, P.O. Box \\ 80203, Jeddah, 21589, Saudi Arabia \\ ${ }^{10}$ Finnish Meteorological Institute, Air Quality, P.O. Box 503, 00101 Helsinki, Finland \\ ${ }^{11}$ Leibniz-Institut für Troposphärenforschung (TROPOS), Permoserstraße 15, 04318 Leipzig, Germany \\ ${ }^{12}$ Department of Chemistry and Microbiology, University of Gothenburg, 41296 Gothenburg, Sweden \\ ${ }^{13}$ Swedish Meteorological and Hydrological Institute, 60176 Norrköping, Sweden
}

Correspondence to: R. Bergström (Robert.Bergstrom@smhi.se)

Received: 21 January 2013 - Published in Atmos. Chem. Phys. Discuss.: 4 April 2013

Revised: 17 July 2013 - Accepted: 19 July 2013 - Published: 3 September 2013

\begin{abstract}
The atmospheric concentration of elemental carbon (EC) in Europe during the six-year period 2005-2010 has been simulated with the EMEP MSC-W model. The model bias compared to EC measurements was less than $20 \%$ for most of the examined sites. The model results suggest that fossil fuel combustion is the dominant source of EC in most of Europe but that there are important contributions also from residential wood burning during the cold seasons and, during certain episodes, also from open biomass burning (wildfires and agricultural fires). The modelled contributions from open biomass fires to ground level concentrations of EC were small at the sites included in the present study, $<3 \%$ of the long-term average of EC in $\mathrm{PM}_{10}$. The modelling of this EC source is subject to many uncertainties, and it was likely underestimated for some episodes.
\end{abstract}

EC measurements and modelled EC were also compared to optical measurements of black carbon (BC). The relationships between EC and BC (as given by mass absorption cross section, MAC, values) differed widely between the sites, and the correlation between observed $\mathrm{EC}$ and $\mathrm{BC}$ is sometimes poor, making it difficult to compare results using the two techniques and limiting the comparability of BC measurements to model EC results.

A new bottom-up emission inventory for carbonaceous aerosol from residential wood combustion has been applied. For some countries the new inventory has substantially different EC emissions compared to earlier estimates. For northern Europe the most significant changes are much lower emissions in Norway and higher emissions in neighbouring Sweden and Finland. For Norway and Sweden, comparisons to source-apportionment data from winter 
campaigns indicate that the new inventory may improve model-calculated EC from wood burning.

Finally, three different model setups were tested with variable atmospheric lifetimes of EC in order to evaluate the model sensitivity to the assumptions regarding hygroscopicity and atmospheric ageing of EC. The standard ageing scheme leads to a rapid transformation of the emitted hydrophobic EC to hygroscopic particles, and generates similar results when assuming that all EC is aged at the point of emission. Assuming hydrophobic emissions and no ageing leads to higher EC concentrations. For the more remote sites, the observed EC concentration was in between the modelled EC using standard ageing and the scenario treating EC as hydrophobic. This could indicate too-rapid EC ageing in the model in relatively clean parts of the atmosphere.

\section{Introduction}

Black carbon (BC) particles, a major component of soot, may heat the atmosphere and thus have a warming effect on the climate. According to the latest IPCC report (Forster et al., 2007 ) the direct radiative forcing (RF) due to $\mathrm{BC}$ from fossil fuel burning is estimated to be $+0.2 \pm 0.15 \mathrm{~W} \mathrm{~m}^{-2}$ with a similar effect due to $\mathrm{BC}$ from biomass burning. The total climate effect of $\mathrm{BC}$ is complex since it also contributes to different semi-direct effects on the cloud cover (e.g. Koch and Del Genio, 2010), which can be both warming and cooling, and it also affects the surface albedo when deposited on snow and ice covered surfaces (e.g. Hansen and Nazarenko, 2004; Hadley and Kirchstetter, 2012). The total RF due to $\mathrm{BC}$ has recently been estimated to be $+1.1 \mathrm{~W} \mathrm{~m}^{-2}$, with a $90 \%$ uncertainty range of +0.17 to $+2.1 \mathrm{~W} \mathrm{~m}^{-2}$ (Bond et al., 2013).

Soot is also of interest because of its adverse health effects. Personal exposure to black carbon is associated with oxidative stress in humans (Sørensen et al., 2003) and with exercise-induced ischemia (Lanki et al., 2006). Janssen et al. (2011) have recently reviewed epidemiological studies of evaluated adverse health effects of PM mass and black carbon particles, $\mathrm{BCP}$ (here $\mathrm{BCP}$ includes $\mathrm{BC}$, elemental carbon (EC) and black smoke). The estimated health effects per $\mu \mathrm{g} \mathrm{m}^{-3}$ were found to be substantially higher for BCP than for $\mathrm{PM}_{10}$ or $\mathrm{PM}_{2.5}$. Another recent review of health effects of PM and its components (Rohr and Wyzga, 2012) also pointed out the importance of carbon-containing PM components, i.e. both EC and OC (organic carbon).

There is an extensive, and sometimes contradictory, nomenclature for various forms of light-absorbing carbon, dependent on measurement techniques (see e.g. Bond and Bergstrom, 2006; Andreae and Gelencsér, 2006). In the present study we use the term EC for carbon that does not volatilize below a defined temperature and $\mathrm{BC}$ for the mass of light-absorbing carbon determined by its light absorption (see Sects. 2.2 and 2.3).

- In thermal analysis, used to measure EC, the particles are collected on a filter and the OC is removed by heating the sample in an inert atmosphere, leaving only the EC. Some OC may, however, char and form compounds which would be detected as EC. The charred organics may be corrected for by monitoring the reflectance (Johnson et al., 1981) or transmission (Birch and Cary, 1996) of the filter during the analysis, and the technique is then called thermal optical analysis (TOA).

- To determine the light-absorptive properties of the aerosol the particles are either collected on a filter prior to the analysis, e.g. Particle Soot Absorption Photometer (PSAP; Bond et al., 1999), Aethalometer (Hansen et al., 1982) and Multi Angle Absorption Photometer (MAAP; Petzold and Schönlinner, 2004), or the absorption can be directly measured in the aerosol, e.g. Photo-Acoustic Soot Spectrometer (PASS) (Arnott et al., 1999). A mass absorption cross section (MAC) is used to transfer the optically measured light absorption (in units of $\mathrm{m}^{-1}$ ) into $\mathrm{BC}$ mass (in units of $\mu \mathrm{g} \mathrm{m}^{-3}$ ). Bond and Bergstrom (2006) suggested a MAC value of $7.5 \mathrm{~m}^{2} \mathrm{~g}^{-1}$ for fresh $\mathrm{BC}$, and this value should increase with ageing of BC. However, a wide range of MAC values (from 2.0 to $25.4 \mathrm{~m}^{2} \mathrm{~g}^{-1}$ ) have been obtained ( $\mathrm{Li}$ ousse et al., 1993). Optical measurements typically generate data at a higher time resolution than filter-based thermal techniques.

Both optical and thermal measurement techniques are important since they complement each other. Optical methods measure the climate-relevant property of soot while TOA measures the mass, a quantity which is likely to be related to the adverse health effects. There are other methods for determining light-absorbing and refractory carbon, such as the Single Particle Soot Photometer (Stephens et al., 2003) and the Soot Particle Aerosol Mass Spectrometer (Onasch et al., 2012), but none of these were used in the present study.

For chemical transport models, TOA results are of main interest since the emission inventories used in the models are usually based on EC measurements. Several European modelling studies of EC or BC have been published. Schaap et al. (2004) performed a one-year simulation of anthropogenic BC and fine aerosol (for 1995) with the LOTOS model. Comparisons of calculated BC-concentrations to available observations from the period 1980s-2001 were interpreted as indicating model underprediction of BC by about a factor of 2. The need for better knowledge of emission factors for BC was pointed out. Tsyro et al. (2007) and Simpson et al. (2007) performed multi-year simulations (20022004) with the EMEP MSC-W model (European Monitoring and Evaluation Programme, Meteorological Synthesizing Centre-West), including both anthropogenic emissions 
and wildfire emissions (with low temporal resolution), and evaluated the model results for EC against two long-term measurement campaigns (the CARBOSOL project, Legrand and Puxbaum, 2007; and the EMEP EC/OC campaign, Yttri et al., 2007). The model generally overestimated EC at the northern measurement sites, especially during winter. Emissions from residential wood combustion (RWC) were pointed out as especially uncertain. Bessagnet et al. (2008) modelled carbonaceous aerosol over parts of Europe (excluding the northern and eastern parts) for one year (2003), using the Chimere model, and included a more detailed emission inventory for wildfire emissions with daily time resolution. Koch et al. (2009) evaluated 17 global models that participated in the AeroCom project. Model-calculated annual mean surface BC concentrations (for 2000) were compared to surface observations, and, for Europe, 13 of the 17 models predicted higher mean $\mathrm{BC}$ concentrations than the observed annual mean EC concentrations from the EMEP EC/OC campaign of 2002-2003. However, individual models gave widely different results (model/observed ratio ranged from 0.5 to 10$)$.

The dominant removal process for $\mathrm{EC}$ is wet deposition; Croft et al. (2005) estimated that about $75 \%$ of the EC is removed by wet deposition and $25 \%$ by dry deposition, based on global model runs. Particle hygroscopicity is important in order to account for wet deposition. In modelling studies it is often assumed that at least part of the EC is emitted as hydrophobic particles. A commonly used assumption is that $80 \%$ of the emitted EC is insoluble and $20 \%$ soluble (e.g. Cooke et al., 1999). After atmospheric processing (ageing) the EC is transformed into more hygroscopic forms. The ageing can be due to several different processes: condensation of organic and inorganic vapours on the particles, coagulation with hygroscopic particles and chemical reactions on the surface, etc. (e.g. Croft et al., 2005).

In the present study, measurements of EC and BC from recent years (2005-2010) have been used to evaluate how the EC concentrations calculated by the EMEP MSC-W model, combined with recently developed emission inventories, compare with the measurements. The number of $\mathrm{EC}$ and $\mathrm{BC}$ observations has increased substantially during the last decade, and the increased interest in carbonaceous aerosol, both from climate and health perspectives, makes it important to evaluate the most recent emission inventories. Data from eight northern/central/western European sites were used and both EC and BC data were evaluated when available. New emission inventories for both anthropogenic emissions (Denier van der Gon et al., 2013) and open biomass fires (Wiedinmyer et al., 2011) were included in the comparison. We have also investigated different EC processing schemes in the model, i.e. how ageing of EC affects the results of the model. The present work also highlights the severe problems in comparing different measurement techniques, used for estimating the concentrations of $\mathrm{EC}$ and $\mathrm{BC}$ in the atmosphere.

\section{Method}

The EMEP MSC-W model was used to model EC concentrations in Europe for the period 2005-2010. The model results were compared to measurements of $\mathrm{EC}$ and $\mathrm{BC}$ at eight sites in Europe, as shown in Fig. 1. Different model assumptions were tested to study how ageing of EC in the model influenced the results. Also, two different emission inventories for residential wood combustion were compared.

\subsection{Measurement stations}

Measurement of EC and BC were collected from eight sites (Fig. 1). The stations were chosen to cover northern, central and western Europe. All stations, except Overtoom, are classified as rural background stations in the European Environment Agency (EEA) Airbase database (http://airclimate.eionet.europa.eu/databases/airbase/), which means that they ideally should be representative of a larger area, and suitable for evaluation of the EMEP MSC-W $50 \mathrm{~km}$-scale model. Melpitz is a rural site (Spindler et al., 2004), but it is located $41 \mathrm{~km}$ NE from Leipzig (Herrmann et al., 2006). This means that it does not formally fulfil the recommendations regarding minimum distance to emission sources in the EMEP guidelines (EMEP/CCC) for siting criteria of regional background stations. However, during transport from the south-west to the site, turbulent mixing is usually efficient, and the EMEP MSC-W model results for $\mathrm{NO}_{2}$ are in good agreement with observations at Melpitz (Table S1), which indicates that influences from Leipzig are well captured by the model. Harwell is also a rural site but located in a densely populated region; it was classified as an agglomeration site by Henne et al. (2010), and could be less representative for larger areas. Overtoom is an urban background station located in Amsterdam in the Netherlands. Mace Head, which is a background marine station, is located on the west coast of Ireland and is a good site for investigating the clean marine air during prevailing westerly/south-westerly winds, occurring more than $50 \%$ of the time (Jennings et al., 2003).

\subsection{EC data}

EC data were retrieved from the EBAS database (ebas.nilu.no, now part of the ACTRIS data center, actris.nilu.no), except the data from Hyytiälä that were provided directly from the Finnish Meteorological Institute (Aurela et al., 2011). All data are based on thermal separation of OC from EC, although the method used varies between the sites (Table 1). All stations, except Melpitz, use TOA techniques for EC quantification, which corrects for OC charring in the initial heating phase. The VDI protocol (VDI2465-2, 1999; Gnauk et al., 2011), used at Melpitz, has no charring correction and is expected to lead to higher EC values compared to TOA (Schmid et al., 2001) and to underestimate OC (ten Brink et al., 2004). 
Table 1. EC and BC measurement techniques and data availability for the stations included in this work.

\begin{tabular}{llllll}
\hline Station & EC method(s) & EC data period & EC size fraction(s) & BC method & BC data period \\
\hline Aspvreten (SE) & EUSAAR-2 & $2008-2010$ & $\mathrm{PM}_{10}$ & PSAP $(525 \mathrm{~nm})$ & $2008-2010$ \\
Birkenes (NO) & QUARTZ and EUSAAR-2 & $2005-2010$ & $\mathrm{PM}_{2.5,10}$ & PSAP $(522 \mathrm{~nm})$ & $2008-2010$ \\
Harwell (GB) & QUARTZ & $2007-2009$ & $\mathrm{PM}_{10}$ & 2 wavelength Aethalometer & $2009-2010$ \\
Hyytiälä (FI) & EUSAAR-1 & $2007-2008$ & $\mathrm{PM}_{1}$ & 7 wavelength Aethalometer & $2005-2010$ \\
Mace Head (IE) & EUSAAR-2 & $2008-2009$ & $\mathrm{PM}_{10}$ & Aethalometer $(880 \mathrm{~nm})$ & $2005-2010$ \\
Melpitz (DE) & VDI-2465, part 2 & $2005-2010$ & $\mathrm{PM}_{2.5,10}$ & MAAP $(670 \mathrm{~nm})$ & $2007-2010$ \\
Overtoom (NL) & NIOSH & $2006-2008$ & $\mathrm{PM}_{2.5}$ & - & - \\
Vavihill (SE) & EUSAAR-2 & $2008-2010$ & $\mathrm{PM}_{10}$ & PSAP $(520 \mathrm{~nm})$ & $2008-2010$ \\
\hline
\end{tabular}

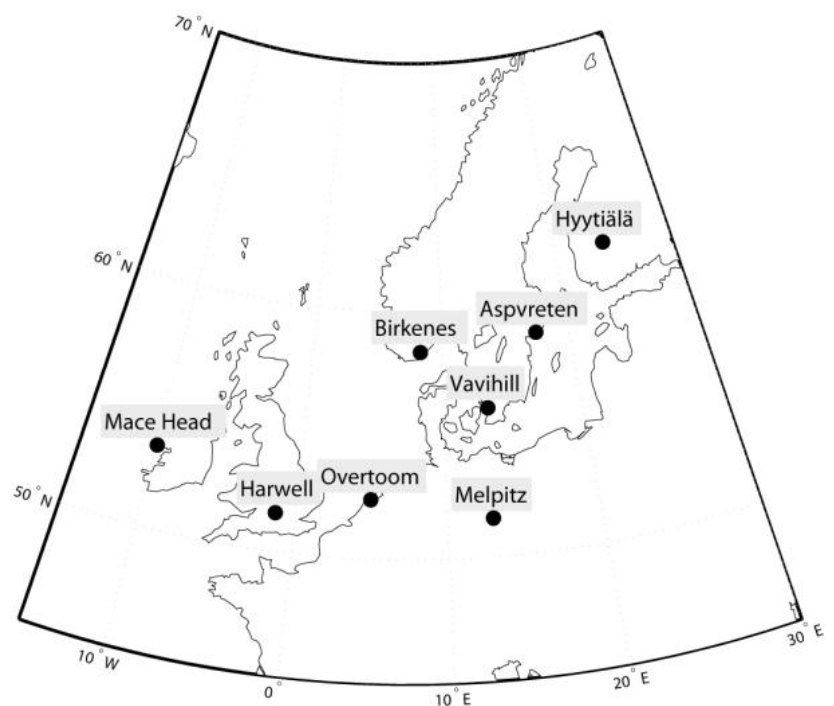

Fig. 1. Map of north-western and central Europe and the locations of the eight stations used in the present study.

The use of different TOA measurement protocols is known to produce differences in results. The protocol QUARTZ (a version of NIOSH 5040, Birch and Cary, 1996) uses a higher temperature in the initial He phase compared to EUSAAR2 (Cavalli et al., 2010); QUARTZ and NIOSH normally give lower EC compared to the EUSAAR-2 protocol. EUSAAR-1 uses fewer temperature steps in the EC phase than EUSAAR2, but the two are otherwise identical. All four TOA protocols use transmission to correct for charring. It is well known that EC determination using even the same separation protocol may produce more than $20 \%$ difference in EC results (Schmid et al., 2001).

In addition to total EC data, we also used sourceapportioned biomass burning EC data from five Nordic stations: Hurdal and Oslo, in Norway (Yttri et al., 2011b); and Råö, Gothenburg (Szidat et al., 2009) and Vavihill (Genberg et al., 2011), in Sweden. One month of levoglucosan data from Hyytiälä (Saarnio et al., 2010) was also used to evalu- ate the modelled EC from open biomass fires and residential wood burning.

\subsection{BC data}

$\mathrm{BC}$ or aerosol absorption coefficients were retrieved from the EBAS database (ebas.nilu.no) for all stations except Aspvreten, for which data were taken directly from the local database in Stockholm. The method used for determining the aerosol absorption varied (see Table 1). At all sites except Melpitz, BC data were acquired using either a PSAP or an Aethalometer, both of which use similar measurement techniques. The particles are collected on a filter and the attenuation is determined by measuring the transmission of a light beam through the filter. To retrieve aerosol absorption (Abs), corrections have to be made to account for the filter material and scattering interference, which are dependent on the method used (Bond et al., 1999). At Melpitz, a MAAP was used. The MAAP monitors the scattering properties of the filter during sampling, which otherwise have to be estimated by measuring the scattering of the aerosol using e.g. a nephelometer. Harwell and Hyytiälä had multi-wavelength Aethalometers; for Harwell BC data $880 \mathrm{~nm}$ was used and for Hyytiälä $520 \mathrm{~nm}$. The correlation between the measurements at different wavelengths were high for the multi-wavelength instruments $(r>0.95)$.

To determine the $\mathrm{BC}$ mass concentrations for Harwell, Hyytiälä and Mace Head a pre-set MAC of $16.6 \mathrm{~m}^{2} \mathrm{~g}^{-1}$ was used for $880 \mathrm{~nm}$ and an inverse wavelength dependence was assumed for the other wavelengths. In addition to the Aethalometer, a MAAP instrument has been deployed at Mace Head since 1 March 2005.

Since the EMEP model is based on EC emissions, we used $\mathrm{EC}$ measurement data to normalize $\mathrm{BC}$, in accordance with the recommendation of Vignati et al. (2010). To distinguish between $\mathrm{BC}$ deduced by MAC values and the ones normalized with $\mathrm{EC}$, the latter ("EC-equivalent $\mathrm{BC}$ ") will be denoted $\mathrm{BC}_{\mathrm{e}}$. The relationships are explained by Eqs. (1)-(3).

$\mathrm{BC}=\mathrm{Abs} / \mathrm{MAC}$ 
$\mathrm{MAC}_{\mathrm{e}}=\mathrm{Abs} / \mathrm{EC}$

$\mathrm{BC}_{\mathrm{e}}=\mathrm{Abs} / \mathrm{MAC}_{\mathrm{e}}$

We determined the station-specific MAC $\left(\mathrm{MAC}_{\mathrm{e}}\right)$ by a least absolute deviation fit (forced through origin) between overlapping absorptions and EC measurements (see Fig. 2). The least absolute deviation was used, rather than least square fitting, to limit the influence of extreme values. The differences in $\mathrm{MAC}_{\mathrm{e}}$ values between the fitting methods were small for all stations except Aspvreten. Since we included data from Aspvreten that were not fully quality controlled, they may have contained some erroneous data points. To be considered as overlapping measurements, $90 \%$ of the EC sampling time had to be covered by $\mathrm{BC}$ measurements. To be able to calculate $\mathrm{MAC}_{\mathrm{e}}$ for Mace $\mathrm{Head}$, the required overlap was lowered to $70 \%$; the lack of EC measurements (only five EC samples with sufficient overlap) made the $\mathrm{MAC}_{\mathrm{e}}$ determination rather uncertain.

A more detailed study of the $\mathrm{BC}$ data was conducted for Hyytiälä for which the Ångström exponent was calculated in order to determine the influence of biomass burning on $\mathrm{BC}$ (Kirchstetter et al., 2004).

\subsection{The EMEP MSC-W model}

In this study the rv4 version of the EMEP MSC-W model (Simpson et al., 2012) was used to calculate the EC concentration in Europe. The EMEP model simulates a wide range of air pollutants, including photochemical oxidants and inorganic and organic aerosols. It is regularly used within the EMEP programme to provide scientific support to the convention on long-range transboundary air pollution (CLRTAP). The model has been extensively compared with measurements of many different compounds (Jonson et al., 2006; Simpson et al., 2006; Tsyro et al., 2007; Fagerli and Aas, 2008; Aas et al., 2012).

The model domain covers all of Europe and has a horizontal resolution of about $50 \mathrm{~km} \times 50 \mathrm{~km}$. Twenty vertical levels are used to cover the troposphere; the lowest model layer is about $90 \mathrm{~m}$ thick and the top of the model is at $100 \mathrm{hPa}$. The EMEP model, with this setup, is designed to study largescale distribution of air pollutants, and we mostly compare model results to measurements from regional background sites.

For the years 2005-2006 we used the PARLAM-PS meteorological driver (Bjørge and Skålin, 1995; Benedictow, 2003). For the later years (2007-2010) the meteorological fields were taken from the European Centre for Medium Range Weather Forecasting Integrated Forecasting System (ECMWF-IFS) model (http://www.ecmwf.int/ research/ifsdocs/). The two meteorological drivers differ to some extent in important meteorological parameters, such
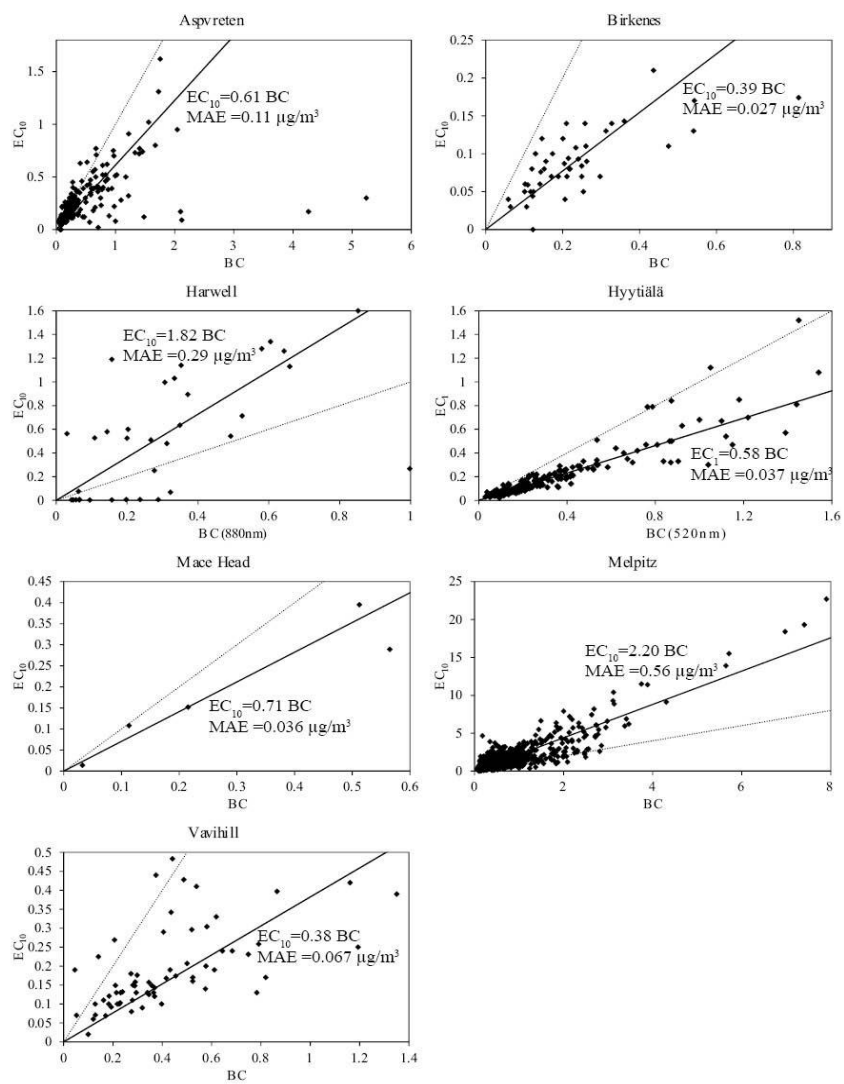

Fig. 2. Scatterplots of measured EC and BC showing data from periods with overlapping thermal and optical measurements. The data shown in these plots were used to calculate the site-specific $\mathrm{MAC}_{\mathrm{e}}$ values (see Table 2) which are used to convert the optical absorption data to $\mathrm{BC}_{\mathrm{e}}$ concentrations. The solid line is the fit and the dotted line is the $1: 1$ line. Note that the $x$ axis shows $\mathrm{BC}$ either provided directly by the Aethalometer or calculated from the absorption data using the assumed MAC value $10 \mathrm{~m}^{2} \mathrm{~g}^{-1}$. MAE is the mean absolute deviation (in EC) from the fitted line. Unit: $\mu \mathrm{g} \mathrm{m}^{-3}$.

as precipitation, which leads to somewhat varying performance for the EMEP model depending on the driver. This is discussed in detail by Tarrasón et al. (2008). For most pollutants the differences are modest, but for $\mathrm{PM}_{2.5}$ somewhat worse results were found with the ECMWF model than with PARLAM-PS, partly due to less transport to Nordic sites with the ECMWF model, leading to underestimated concentrations there and poorer correlation between calculated and observed $\mathrm{PM}_{2.5}$. Somewhat worse model results for EC can thus be expected for the years 2007-2010 than for 20052006, at least at the northerly sites.

The EMEP MSC-W model uses two size modes for particles, fine and coarse aerosol, although assigned sizes for some of the coarse aerosol vary with compound. The parameterization of the wet deposition processes in the EMEP model is based on Berge and Jakobsen (1998) and includes in-cloud and sub-cloud scavenging of gases and particles. 
Further details, including scavenging ratios and collection efficiencies for particles, are given in Simpson et al. (2012).

In this study we used different emission inventories for the carbonaceous aerosol than used in Simpson et al. (2007), Tsyro et al. (2007) and Bergström et al. (2012), and slightly different assumptions regarding the emitted EC. In our base case scenario, the model anthropogenic emissions of EC in $\mathrm{PM}_{2.5}\left(\mathrm{EC}_{2.5}\right)$ were treated as consisting of $80 \%$ hydrophobic ("fresh") EC and $20 \%$ hygroscopic ("aged") EC when emitted into the atmosphere. The fresh EC has a low in-cloud scavenging ratio; in this study we used $W_{\text {in }}=5 \times 10^{4}$ for fresh EC. Aged/hygroscopic EC was assumed to be internally mixed with the soluble inorganic (and organic) aerosol components, and we used the same scavenging ratio as for sulfate, $W_{\text {in }}=1 \times 10^{6}$. The collection efficiency for belowcloud scavenging is low for all fine particles in the model ( $\bar{E}=0.02$ ), so wet deposition is small for the hydrophobic EC. Note that compared to Tsyro et al. (2007), the present version of the EMEP model has more efficient wet deposition of EC.

Recently, the model has been extended with a new particulate carbonaceous matter (PCM) version using the volatility basis set (VBS) approach (Donahue et al., 2006) for the organic aerosol (Bergström et al., 2012). The EMEP PCM model uses the same inorganic and gas phase organic chemistry scheme, and deposition routines, as the standard EMEP MSC-W model (Simpson et al., 2012), with additional secondary organic aerosol forming reactions (Bergström et al., 2012). The model setup used in the present study was similar to the one used by Bergström et al. (2012); the main differences were in parts of the emissions handling. In this study we used hourly variation of anthropogenic emissions (as in Simpson et al., 2012), while Bergström et al. (2012) used simple day-night factors. We also used a newer emission inventory for open biomass fires (wildfires, agricultural burning and other managed vegetation burns), the Fire INventory from NCAR version 1.0 (FINNv1, Wiedinmyer et al., 2011). FINNv1 has high spatial resolution and a better temporal resolution (daily) than the GFED emissions ( 8 day), used in earlier studies with the EMEP model. Biomass burning emissions are subject to large uncertainties (e.g. Wiedinmyer et al., 2006; Paton-Walsh et al., 2012). The satellite-based fire detection systems may miss some fires completely or partly (due to cloud cover, or very rapid fire progression; PatonWalsh et al., 2012). In a comparison of different methods for estimating emissions (Paton-Walsh et al., 2012) FINNv1 was found to produce significantly lower emission estimates than other methods (e.g. black carbon emissions were only about $1 / 3$ of the estimates using GFEDv3.1).

Primary anthropogenic EC and organic aerosol emissions were taken from the EUCAARI anthropogenic carbonaceous aerosol emission inventory by Denier van der Gon et al. (2009) (see also Visschedijk et al., 2009). Other anthropogenic emissions were taken from the standard EMEP emission inventory (Mareckova et al., 2009). In this study we also tested a new emission inventory for residential wood combustion (Denier van der Gon et al., 2013). In the following, this inventory will be denoted TNO new RWC.

Emissions were distributed vertically as described by Simpson et al. (2012). Most of the anthropogenic EC emissions come from low-level sources (residential heating, road traffic and other mobile sources etc.). More than $90 \%$ of the anthropogenic EC emissions (excluding open burning) are released in the lowest model level. Emissions from the open burning of vegetation (from FINNv1) were treated differently; they were homogeneously distributed over the eight lowest model layers (up to $\sim 2 \mathrm{~km}$ height), loosely based on data from Sofiev et al. (2009). This means that the vegetation fire EC has a very different vertical distribution than the EC from other sources. In this study we focus on near-surface EC; the importance of open biomass fires will therefore be relatively small, since a large fraction of the (effective) emissions occur at high altitude. For climate impacts biomass fires are of much larger importance.

Atmospheric processing (ageing) of the EC transforms it into hygroscopic particles that are more easily scavenged by precipitation. We treated the ageing in a simplified way, similar to the method described by Tsyro et al. (2007). The parameterization of (anthropogenic) EC ageing is based on the work by Riemer et al. (2004), who simulated soot ageing in a polluted environment, dominated by fossil fuel combustion, using a mesoscale model and constructed a simple parameterization of ageing rates dependent on time of day and altitude. Riemer et al. (2004) found that the ageing was most efficient during daylight hours, when condensation of sulphuric acid and ammonium nitrate dominates. Ageing of soot was slower at low altitudes (close to the sources) than above the source region. In the EMEP model, the timescale (e-folding time) for EC ageing is $8 \mathrm{~h}$ (rate $3.5 \times 10^{-5} \mathrm{~s}^{-1}$ ) for the three lowest model levels (up to $\sim 300 \mathrm{~m}$ ). At higher altitudes ageing is more rapid with a lifetime of $2 \mathrm{~h}$ for the fresh EC. During the dark hours (sun below the horizon) the EC ageing rate is low, $9.2 \times 10^{-6} \mathrm{~s}^{-1}$, corresponding to a lifetime of $30 \mathrm{~h}$. This rate is also based on Riemer et al. (2004) and it is due to ageing by coagulation (condensation was not effective during night in the model used by Riemer et al., 2004).

In contrast to the anthropogenic emissions, all of the EC emitted from open biomass fires is treated as hygroscopic, already at the point of emission, in the standard version of the EMEP MSC-W model.

In the present study, model runs using the standard assumption of ageing will be referred to as STD. Since the EC ageing parameterization is very simplified (and based on a model study of ageing in polluted conditions), we also included two sensitivity tests regarding the EC ageing. In the first case (FRESH) all atmospheric ageing of EC was neglected and $100 \%$ of the emissions were assumed to be hydrophobic (including the open biomass fire EC). The FRESH model leads to more efficient long-range transport of EC than 
the standard model version. It gives a maximum estimate of EC.

In the second test (AGED) all EC was treated as hygroscopic already at the point of emission. We expect that the AGED model overestimates the water affinity of EC originating from, e.g., diesel combustion (e.g. Weingartner et al., 1997; Tritscher et al., 2011), but it may perhaps be more realistic for EC from wood burning where salts are co-emitted with the EC, making the particles less hydrophobic (Engelhart et al., 2012).

\section{Results and discussion}

\subsection{EC and BC}

We found large differences between $\mathrm{EC}$ and $\mathrm{BC}$ for most of the stations investigated in this study (Fig. 2). All BC data were normalized with $\mathrm{EC}$ data from the same station to produce $\mathrm{EC}$-equivalent $\mathrm{BC}$ values, $\mathrm{BC}_{\mathrm{e}}$, using site-specific $\mathrm{MAC}_{\mathrm{e}}$ values. The correlation between the two measurement techniques varied between the stations (Table 2). Furthermore, the $\mathrm{MAC}_{\mathrm{e}}(550 \mathrm{~nm})$ values varied from 5.5 (Melpitz) to $45.9 \mathrm{~m}^{2} \mathrm{~g}^{-1}$ (Hyytiälä), which was more than was expected because of the use of different EC protocols. However, the Aethalometers at Hyytiälä, Harwell and Mace Head operated at higher pre-set MAC values and are expected to be $\sim 2$ times higher due to multiple scattering (Weingartner et al., 2003). MAC values for ambient aerosols in polluted regions are often in the range $9-12 \mathrm{~m}^{2} \mathrm{~g}^{-1}$; however, the variability of reported MAC is large, from about 2 to $25 \mathrm{~m}^{2} \mathrm{~g}^{-1}$ (Bond and Bergstrom, 2006, and references therein; Cheng et al., 2011). For Melpitz, most of the difference between the $\operatorname{MAC}_{\mathrm{e}}(550 \mathrm{~nm})$ value $\left(5.5 \mathrm{~m}^{2} \mathrm{~g}^{-1}\right)$ and the expected value $\left(\sim 10 \mathrm{~m}^{2} \mathrm{~g}^{-1}\right)$ can be traced to the EC method used, which overestimates $\mathrm{EC}$ and thus gives a lower $\mathrm{MAC}_{\mathrm{e}}$ value.

The data in Fig. 2 and Table 2 show that comparison of BC data from different stations, calculated using the same MAC value for all sites, is not meaningful. The differences between the station-specific $\mathrm{MAC}_{\mathrm{e}}$ values are larger than the differences that would be expected because of uncertainties in the EC measurements. Based on these results, optical methods seem inappropriate for determining ambient EC mass without a secondary method validating the measurement.

\subsection{EC model results}

The calculated six-year mean surface level EC concentration for 2005-2010 is shown in Fig. 3a. The highest modelled EC concentrations are found in urban and industrialized areas; in densely populated parts of western and central Europe the mean concentration of EC generally range from 0.3 to $1.2 \mu \mathrm{g} \mathrm{m}^{-3}$ (or somewhat higher in emission hotspots). At three of the sites covered in the present study (Melpitz, Overtoom and Harwell) EC concentrations are relatively high $\left(0.5-1.7 \mu \mathrm{g} \mathrm{m}^{-3}\right.$, obs. mean conc.), while the other sites are
Table 2. Correlation between EC and BC (expressed as $r$ values) and site-specific mass absorption cross sections (MAC) used in this study to form the EC-equivalent $\mathrm{BC}\left(\mathrm{BC}_{\mathrm{e}}\right)$. $\mathrm{MAC}_{\mathrm{e}}$ values were obtained by normalising $\mathrm{BC}$ measurements with simultaneously observed EC. The normalization was done by minimizing the absolute deviation of the $\mathrm{BC}_{\mathrm{e}}$ from the observed $\mathrm{EC}$ (see text). The $\mathrm{MAC}_{\mathrm{e}}$ values adjusted to $550 \mathrm{~nm}$ are also shown. $\mathrm{EC}$ in $\mathrm{PM}_{10}$ was used in the calculations for all stations except Hyytiälä, for which EC in $\mathrm{PM}_{1}$ was used.

\begin{tabular}{lllll}
\hline Station & $r$ & MAC & MAC $_{\mathrm{e}}$ & $\begin{array}{l}\mathrm{MAC}_{\mathrm{e}} \\
(550 \mathrm{~nm})\end{array}$ \\
\hline Aspvreten & 0.52 & - & 16.3 & 15.5 \\
Birkenes & 0.73 & - & 25.9 & 24.6 \\
Harwell & 0.60 & $16.6(880 \mathrm{~nm})$ & 9.14 & 14.6 \\
Hyytiälä & 0.91 & $28.1(520 \mathrm{~nm})$ & 48.6 & 45.9 \\
Mace Head & $0.94^{*}$ & $16.6(880 \mathrm{~nm})$ & $23.5^{*}$ & $37.6^{*}$ \\
Melpitz & 0.87 & - & 4.55 & 5.5 \\
Vavihill & 0.59 & - & 26.2 & 24.8 \\
\hline
\end{tabular}

* Only nine EC samples were available for Mace Head, and of these only one had more than $90 \%$ overlapping BC measurements. Five of the samples had over $70 \%$ overlap and these were used here.
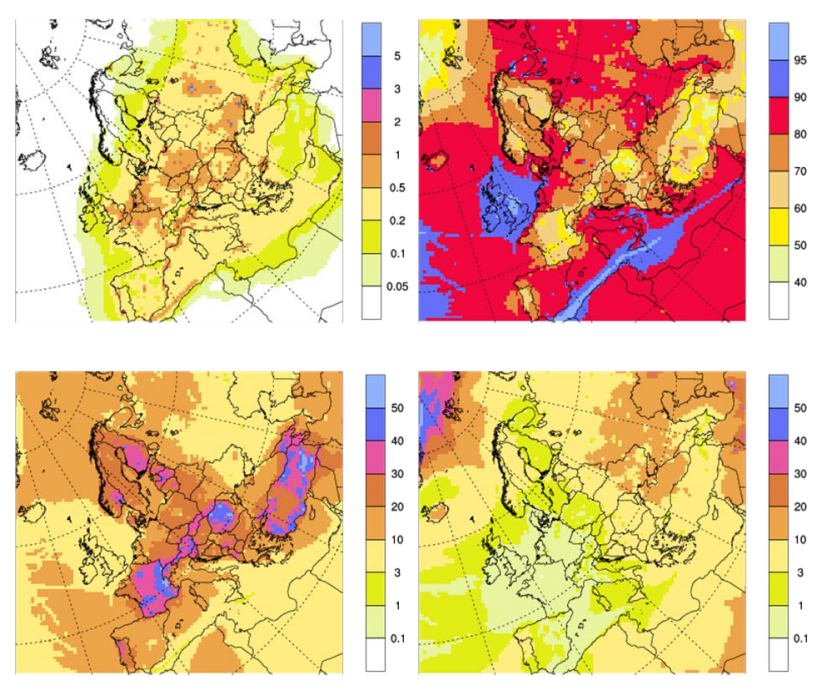

Fig. 3. (a) Six-year mean concentration of $\mathrm{EC}$ in $\mathrm{PM}_{10}\left(\mathrm{EC}_{10}\right)$, for 2005-2010, calculated with the standard model setup and the most recent emission estimates (top left). Unit: $\mu \mathrm{g} \mathrm{m}^{-3}$. (b) Top right: fossil fuel fraction of $\mathrm{EC}_{10}$ (in \% of the total model $\mathrm{EC}_{10}$ ). (c) Bottom left: residential wood combustion (RWC) fraction of $\mathrm{EC}_{10}(\%)$. (d) Bottom right: fraction of $\mathrm{EC}_{10}$ from open biomass burning, including wildfires and agricultural fires (\%). Note the different scales for the different maps.

located in cleaner regions (mean obs. EC, $0.1-0.25 \mu \mathrm{g} \mathrm{m}^{-3}$ ). Fossil fuel sources dominate the modelled surface level EC (more than $70 \%$ in most countries, see Fig. 3b), but residential wood combustion contributes substantially in some countries (e.g. France, Austria, Norway, Finland, Latvia and Romania), where $30-50 \%$, or more, of the EC come from 
RWC (Fig. 3c). The calculated contribution to near-ground EC from open biomass fires is relatively low $(<10 \%$ as sixyear mean) except in parts of the Ukraine and southern Russia, where it is above $10 \%$ (Fig. 3d).

\subsection{Model and measurement comparison}

When comparing model EC concentrations (or any air pollutant) to measurements it is important to remember that the model results represent grid point average concentrations $(50 \mathrm{~km} \times 50 \mathrm{~km} \times 90 \mathrm{~m}$, in this study), which limits the ability to reproduce local concentration gradients or short-term fluctuations. This limitation is especially important for primary emitted species, such as EC, and means that modelpredicted concentrations will have a lower variability than observations.

There are many other factors that can also contribute to model-measurement disagreement. The main (modelrelated) factors are (i) emission amounts and distribution; (ii) model transport (wind directions and strength); (iii) vertical dispersion, too much or too little; (iv) wet and dry deposition; and (v) time variation of emissions. Points (ii) and (iii) are the same for different pollutants (but vary with location), and, to address these factors, we have included a comparison of modelled $\mathrm{NO}_{2}$ concentrations to measurements at six of the sites in this study. Emissions and deposition are expected to be better known for $\mathrm{NO}_{\mathrm{x}}$ than for EC (e.g. Granier et al., 2011; Reis et al., 2009; Simpson et al., 2007; Fowler et al., 2009), so if the model works well for $\mathrm{NO}_{2}$ at a given site, it is likely that points (ii) and (iii) are relatively well modelled.

Results from the $\mathrm{NO}_{2}$ evaluation are given in Table $\mathrm{S} 1$. The model performed rather well for Harwell, Hyytiälä, Melpitz and Vavihill with small (average) bias (within $22 \%$ of the measured conc.) and fairly good correlation ( $r$ ranging from 0.71 to 0.83 , for daily averages). For Aspvreten $\mathrm{NO}_{2}$ was overestimated by $43 \%$ and the correlation was a bit lower $(r=0.61)$. The results for Birkenes were worse, with an average bias of $89 \%$ and moderate correlation $(r=0.64)$. The good performance for Harwell, Hyytiälä, Melpitz and Vavihill indicates that the model works rather well with respect to points (ii) and (iii) at these sites. For Aspvreten and (especially) Birkenes this is less certain, and this should be kept in mind when analysing the model performance for EC.

Model-simulated EC was compared to measurements of EC (Figs. 4, 5, 6 and Table S2a; detailed time series plots are shown in the Supplement) and $\mathrm{BC}_{\mathrm{e}}$ (Fig. 7 and Table S2b). In this section, we discuss model results using the standard model version (STD), with the most updated emission inventories (TNO new RWC). Sensitivity tests with the EUCAARI emission inventory for residential wood combustion and alternative assumptions regarding the hygroscopicity and ageing of EC are presented in Sects. 3.4 and 3.6, respectively.

The model performed well when compared to measurements of (long-term average) EC concentrations at most sites included in this study; for EC the model bias was relatively
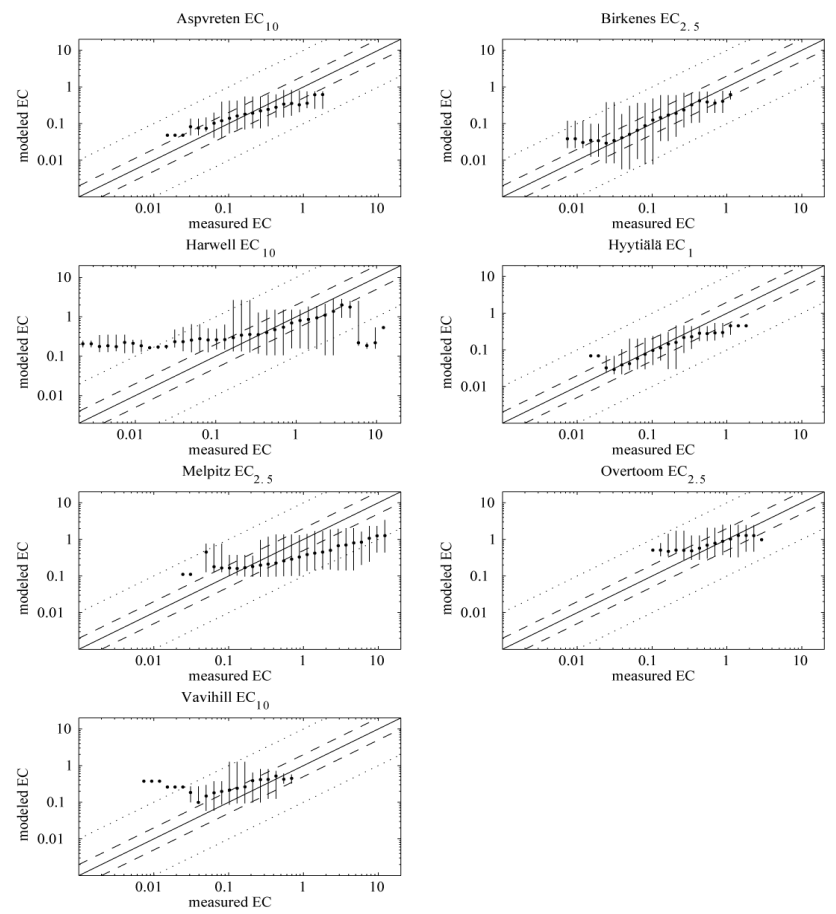

Fig. 4. Scatterplots of measured and modelled EC (standard model setup, STD) for seven European measurement stations: (a) Aspvreten $\mathrm{EC}_{10}$, (b) Birkenes $\mathrm{EC}_{2.5}$, (c) Harwell $\mathrm{EC}_{10}$, (d) Hyytiälä $\mathrm{EC}_{1}$, (e) Melpitz $\mathrm{EC}_{2.5}$, (f) Overtoom $\mathrm{EC}_{2.5}$, and (g) Vavihill $\mathrm{EC}_{10}$. The measured EC are divided into logarithmically spaced concentration bins. Each order of magnitude is divided into 10 bins. The points represent the median of the model results for each concentration bin of measured EC. The vertical lines show the range of model results for each bin. Solid lines represent $1: 1$ lines. Dashed lines represent $2: 1$ and $1: 2$ lines, and dotted lines represent $10: 1$ and $1: 10$ lines. Unit: $\mu \mathrm{g} \mathrm{m}^{-3}$.

low, within $\pm 20 \%$, except for Melpitz ( $-69 \%$ ) and Vavihill $(+66 \%)$ (see below). As expected, the model variability was lower than the observed one (Fig. 4), and the mean absolute error (MAE) of the model concentrations compared to the EC measurements was 36-45\%, at five of the eight sites, but higher for Melpitz, Vavihill and Harwell (as discussed below). The correlation coefficients, $r$, between modelled and measured EC, ranged from 0.45 at Harwell to 0.91 at Mace Head (Table S2a; note that Mace Head only had nine EC measurements).

The largest model bias $\left(-0.98 \mu \mathrm{g} \mathrm{m}^{-3}\right)$ was found at Melpitz. The MAE for $\mathrm{EC}_{2.5}$ at this site was $0.99 \mu \mathrm{g} \mathrm{m}^{-3}(70 \%)$. The largest absolute differences were found for the winter samples (Fig. 5e); however, the relative differences between model and measurements were larger for the summer periods, where a factor of 4 to 8 difference was not uncommon. As can be seen in Figs. 4e and S1 many of the measurements are between 2 and 10 times higher than calculated by the model. The same problems are seen when comparing model results to $\mathrm{BC}_{\mathrm{e}}$ (Fig. 7f). Similar results were found 

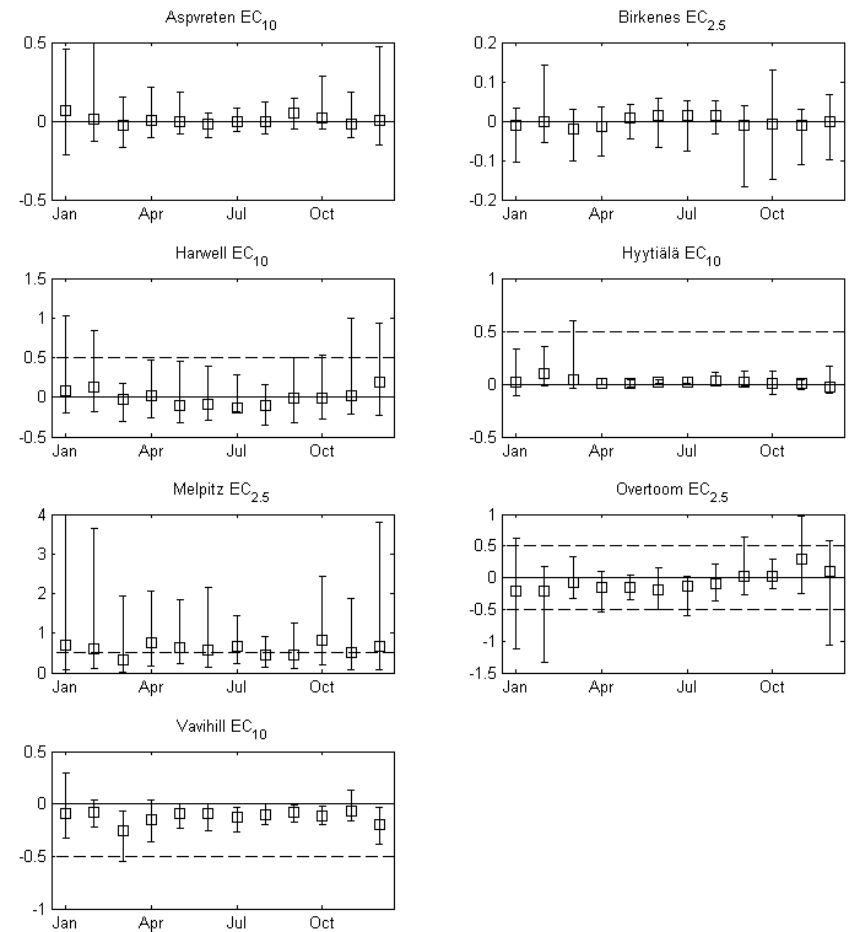

Fig. 5. The seasonal variation of the difference between measured and modelled EC (standard model setup, STD). Boxes show the medians of measured EC - model EC for each month. Error bars represent 10th and 90th percentiles. Dashed lines $= \pm 0.5 \mu \mathrm{g} \mathrm{m}^{-3}$. Note that the error bar for Melpitz (January) ends outside the $y$ axis scale (90th percentile $=6.75$ ). Unit: $\mu \mathrm{g} \mathrm{m}^{-3}$.

in an earlier EC modelling comparison, using the CTM2 model, where observed EC at Melpitz was a factor of 2 to 9 higher than the model EC (Skeie et al., 2011). Stern et al. (2008) compared five different chemical transport models to observations from northern Germany during highly polluted conditions. None of the models could reproduce the very high EC concentrations observed at Melpitz during February-March 2003. For other air pollutants, such as $\mathrm{NO}_{2}$, $\mathrm{SO}_{2}, \mathrm{NO}_{3}^{-}$and $\mathrm{SO}_{4}^{2-}$, model results were much better than for EC. Stern et al. (2008) suggested that the large underestimations of EC may be an indication that emissions in the central European region were underestimated during these episodes.

To a minor extent the differences between the observations and model results for Melpitz are due to the EC measurement technique used (without charring correction; see Yttri et al., 2011a). This affects $B C_{e}$ values as well, through the stationspecific $\mathrm{MAC}_{\mathrm{e}}$. However, this should not lead to discrepancies as large as those found here. An earlier comparison between VDI and TOA shows that the difference for urban samples should not be greater than a factor of two (Schmid et al., 2001).

There can be several other explanations for the poor agreement between the modelled EC concentrations and the mea-

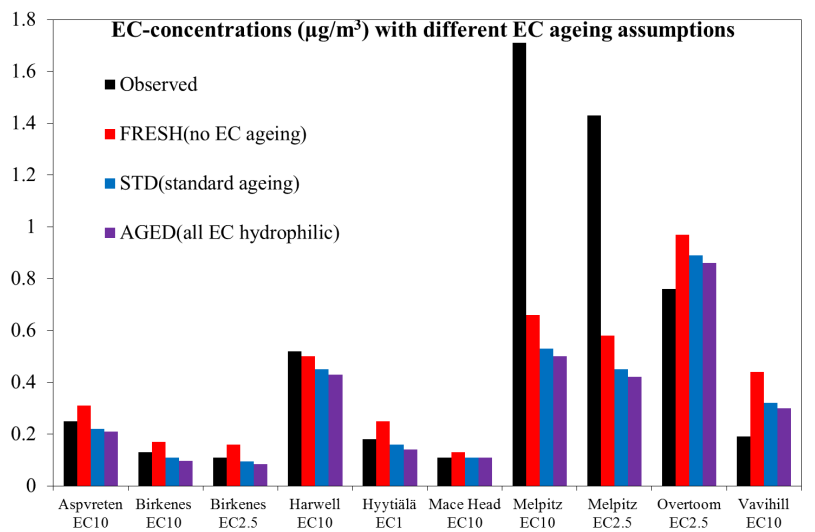

Fig. 6. Comparison of observed EC to model results from simulations using three different assumptions regarding the EC hygroscopicity and atmospheric ageing. The diagram shows average EC concentrations for the periods with measurements: observed (black); FRESH $=$ model with all EC treated as externally mixed and hydrophobic, no ageing (red); STD = standard model version, including atmospheric ageing of EC (blue); AGED = model with all EC treated as hydrophilic already at emission (purple); unit: $\mu \mathrm{g} \mathrm{m}^{-3}$. Note that data are from different periods for different stations (see Tables 1 and S2a).

surements at Melpitz. Either some emission sources are severely underestimated in the emission inventories or the site is influenced by relatively local (on a $50 \mathrm{~km} \times 50 \mathrm{~km}$ scale) emission sources and/or frequent inversions leading to concentrations that are not representative of a relatively coarse model resolution. Local combustion sources (e.g. wood stoves) can be detected (Spindler et al., 2012). However, the population density is relatively low around Melpitz, so the importance of this source is expected to be low and it should not be important during summer. A long-term study of the influence of long-range transport from the east and west to Melpitz has shown that easterly wind conditions, especially during winter, lead to higher total $\mathrm{PM}_{10}$ and higher EC concentrations than westerly winds (Spindler et al., 2012). However, westerly wind conditions are much more frequent; about $60 \%$ of the time the wind direction is south-westerly, compared to $17 \%$ for easterly winds (Spindler et al., 2012). In the present study, $62 \%$ of the $\mathrm{EC}_{2.5}$ measurements at Melpitz were underestimated by more than $40 \%$; in contrast, the $\mathrm{NO}_{2}$ concentrations were fairly well modelled (average model bias $5 \%, r=0.71$; see Table S1). This means that, unless there were local EC emissions influencing the measurements, part of the reason for the too-low model EC is likely to be underestimation of larger-scale EC emissions to the (south) west of Melpitz.

For Vavihill (Figs. 4g, 5g, S2) the model generally overestimated EC concentrations compared to measurements. This was probably partly due to a systematic error in the EC measurements. EC results from the Lund University DRI carbon analyser were about $20 \%$ lower compared to the mean of 
other European analysers in several intercomparisons within EUSAAR (results to be published). However, the model bias in the present study $(+66 \%)$ was larger than the expected error. In addition the correlation between the modelled and measured EC was rather low $(r=0.54)$. The model results for $\mathrm{NO}_{2}$ were much better (bias $+22 \%, r=0.74$ ). This may indicate that $\mathrm{EC}$ emissions from some sources that occasionally affect Vavihill are overestimated in the emission inventories used in the model.

For Aspvreten (Figs. 4a, 5a, S3), model results were in better agreement with observed EC for 2008-2009 than for 2010. During 2010 there were a handful of high EC measurements $\left(1-1.8 \mu \mathrm{g} \mathrm{m}^{-3}\right)$. The observed EC is two to six times higher than the modelled concentrations for those events. The EC peaks occurred in winter, spring and autumn and were not correlated with especially high observed $\mathrm{NO}_{2}$ concentrations. The sources of these high peaks are unknown, but most of them are correlated with small model peaks of EC from fossil sources, or from RWC, so it is possible that some of these emissions are underestimated; alternatively, some local EC emissions may have influenced the site during those days.

Model results for $\mathrm{EC}_{2.5}$ at Birkenes (Figs. 4b, 5b, S4) were in fairly good agreement with observations, clearly better than the results for $\mathrm{NO}_{2}$. The model bias for $\mathrm{EC}_{2.5}$ was low $(-12 \%)$, the MAE was only $0.05 \mu \mathrm{g} \mathrm{m}^{-3}$ (45\%), and the correlation between model and measurements was reasonably good $(r=0.71)$. Although the results for this site were generally in good agreement with the EC measurements, there were some episodes when the model overestimated EC substantially; this seems to be largely due to overestimation of the contribution from some fossil source(s). The Birkenes results are discussed in more detail in Sect. 3.5.

At Mace Head the model-calculated EC was in good agreement with the limited number of $\mathrm{EC}$ measurements available (Fig. S5). The optically measured $\mathrm{BC}_{\mathrm{e}}$ was, however, underestimated most of the time. Frequently the relative underestimation was large; about $5 \%$ of the hourly $\mathrm{BC}_{\mathrm{e}}$ measurements were underestimated by a factor of 10 or more. No seasonal trend could be seen for the difference between $\mathrm{BC}_{\mathrm{e}}$ and modelled EC at Mace Head as these events occurred all year round. The bulge of $\mathrm{BC}_{\mathrm{e}}$ measurements between 0.01 and $0.1 \mu \mathrm{g} \mathrm{m}^{-3}$, which were underestimated by the model (Fig. 7e), was also seen when comparing the Aethalometer data with simultaneous MAAP measurements from Mace Head. The irregular behaviour of the Aethalometer during clean conditions is related to its minimum detection limit (71 $\mathrm{ng} \mathrm{m}^{-3}$ for an hourly average, according to Arnott et al., 2003).

Harwell (Figs. 4c, 5c, S6) had the lowest correlation between modelled and measured EC of all the sites $(r=0.45)$. The anomalous EC results at Harwell are due to some very high observed values $\left(5-13 \mu \mathrm{g} \mathrm{m}^{-3}\right)$ during the first four months of the measurement period (see Fig. S6); these were not seen in the model. If the first 95 data points (out of a total of 672) are excluded, the model $\mathrm{EC}_{10}\left(\mathrm{EC}\right.$ in $\left.\mathrm{PM}_{10}\right)$ is fairly
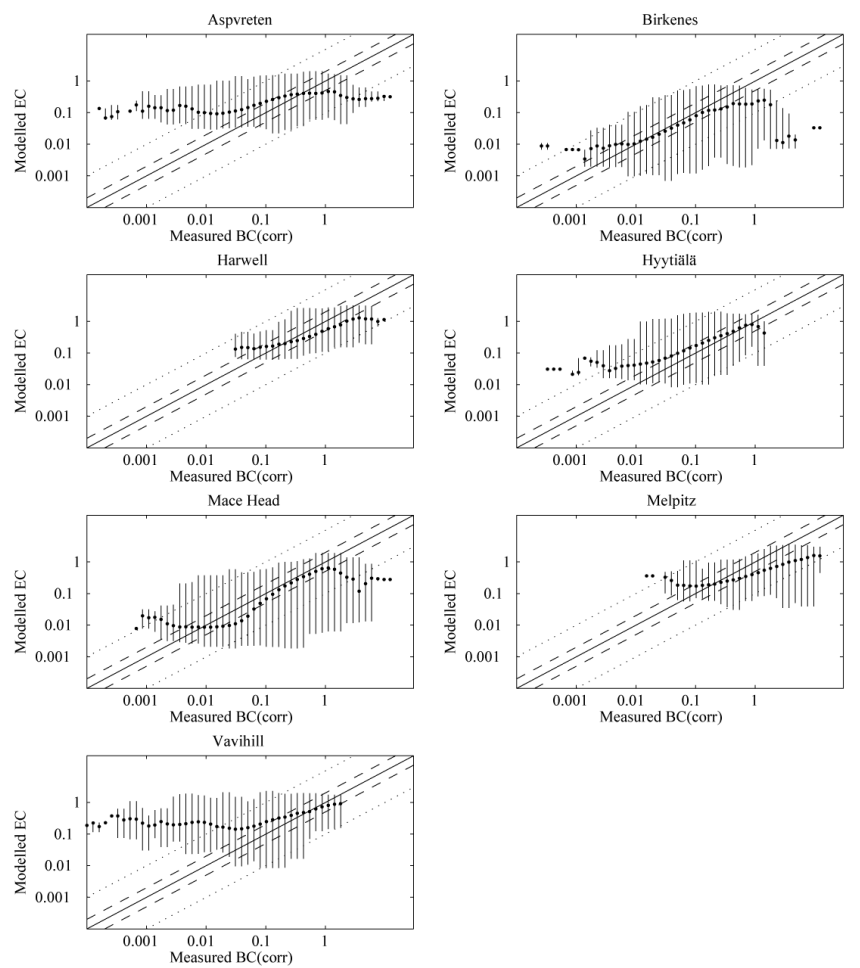

Fig. 7. Scatterplots of hourly measured $\mathrm{BC}_{\mathrm{e}}$ and modelled $\mathrm{EC}_{10}$ (STD model version) for seven European measurement stations: (a) Aspvreten, (b) Birkenes, (c) Harwell, (d) Hyytiälä, (e) Mace Head, (f) Melpitz, and (g) Vavihill. The points represent the median of model results for each concentration bin of measured $\mathrm{BC}_{\mathrm{e}}$. Each order of magnitude is divided into 10 bins. The vertical lines represent all model results for each bin. Solid lines represent $1: 1$ lines. Dashed lines represent $2: 1$ and $1: 2$ lines and dotted lines represent $10: 1$ and $1: 10$ lines. Unit: $\mu \mathrm{g} \mathrm{m}^{-3}$.

well correlated with the observations $(r=0.69)$ and the average bias is low $(-0.1 \%)$. The measurement data from Harwell contain a large number of very low or zero measurements; about $30 \%$ of the daily data are below $0.04 \mu \mathrm{g} \mathrm{m}^{-3}$. These points suggest an error in the measurements. The $\mathrm{BC}_{\mathrm{e}}$ measurements (Fig. 7c) are much higher than modelled values at Harwell, and also higher than the measured EC data. This can be explained by the limited period of overlapping EC and BC measurements (two months). In fact, the model EC for Harwell was in better agreement with unconverted $\mathrm{BC}$ values than with the $\mathrm{EC}$-normalized $\mathrm{BC}_{\mathrm{e}}$ values.

For all stations except Harwell, the correlation coefficients between model results and measurements were lower for $\mathrm{BC}_{\mathrm{e}}$ (hourly data, $r$ in the range 0.17[Aspvreten] to 0.68 [Hyytiälä]) than for EC (daily or longer sampling time, $r$ from 0.45[Harwell] to 0.91[Mace Head]). The largest differences in correlation coefficients were found at Aspvreten $\left(r_{\mathrm{BCe}}=0.17, r_{\mathrm{EC} 10}=0.63\right)$ and Birkenes $\left(r_{\mathrm{BCe}}=\right.$ $\left.0.34, r_{\mathrm{EC} 10}=0.76\right)$. Lower correlation for $\mathrm{BC}_{\mathrm{e}}$ is not unexpected since the model emissions are based on $\mathrm{EC}$ rather than 
$\mathrm{BC}$, and the assumption of a single constant $\mathrm{MAC}_{\mathrm{e}}$ value for each station is clearly a simplification. In reality, the optical properties of the EC containing particles vary for different sources and change depending on atmospheric processing. The overall lower correlation for $\mathrm{BC}_{\mathrm{e}}$ is partly due to the high time resolution of the measurements. Comparing daily averages of observed $\mathrm{BC}_{\mathrm{e}}$ with the corresponding model $\mathrm{EC}$ resulted in higher correlation coefficients than comparisons of hourly values. At four of six sites (Harwell, Hyytiälä, Melpitz and Vavihill) the model results were even better correlated with $\mathrm{BC}_{\mathrm{e}}$ (daily) than with the measured $\mathrm{EC}$.

\subsection{Residential wood combustion - revised emission inventory}

The EC/OC emission inventory by Denier van der Gon et al. (2009), prepared as part of the EUCAARI project (Kulmala et al., 2011), was a significant improvement compared to earlier European inventories in terms of spatial resolution of such emissions $(\sim 7 \times 7 \mathrm{~km})$ and provided a more recent base year (2005, instead of 1995 from Schaap et al., 2004). It also included a revised estimate of the wood use for residential heating.

The EUCAARI EC/OC inventory was constructed by starting from a consistent $\mathrm{PM}_{10}$ and $\mathrm{PM}_{2.5}$ inventory, based on the IIASA GAINS model (http://gains.iiasa.ac.at/ models/). A review of wood use activity data was done. This combined statistics and usage data from various sources, looking at wood availability within countries, and grouping countries according to climate, wood availability and wood stove technological development. When usage data were missing for a particular country, the technology combinations were estimated based on the country group average. Over the entire UNECE-Europe domain this increased the estimated annual wood use by approximately $20 \%$. Next, an extensive literature review was done to obtain and/or compile representative PM fractions of EC and OC for every relevant source/technology combination. The PM inventory used as a base to estimate the EC and OC emissions was partly based on country-specific emission factors through the country consultation process coordinated by IIASA. The total $\mathrm{EC}_{2.5}$ emissions in UNECE-Europe in 2005 were $622 \mathrm{kt}$ according to the EUCAARI inventory. Contributions from different sources are shown in Fig. 8: road transport, other mobile sources and machinery, and residential combustion dominate, with more than $3 / 4$ of the emission total. Residential wood combustion was estimated to contribute about $12 \%$ to the total $\mathrm{EC}_{2.5}$ emissions.

Since the EUCAARI effort focussed on obtaining the most representative EC and OC fractions, the absolute total PM emissions from RWC remained unchanged except for countries where a correction was done on the activity data. Although not realized at the time of the construction of the EUCAARI EC/OC inventory, this procedure introduced an artefact into the $\mathrm{EC}$ and $\mathrm{OC}$ estimates that can be best explained

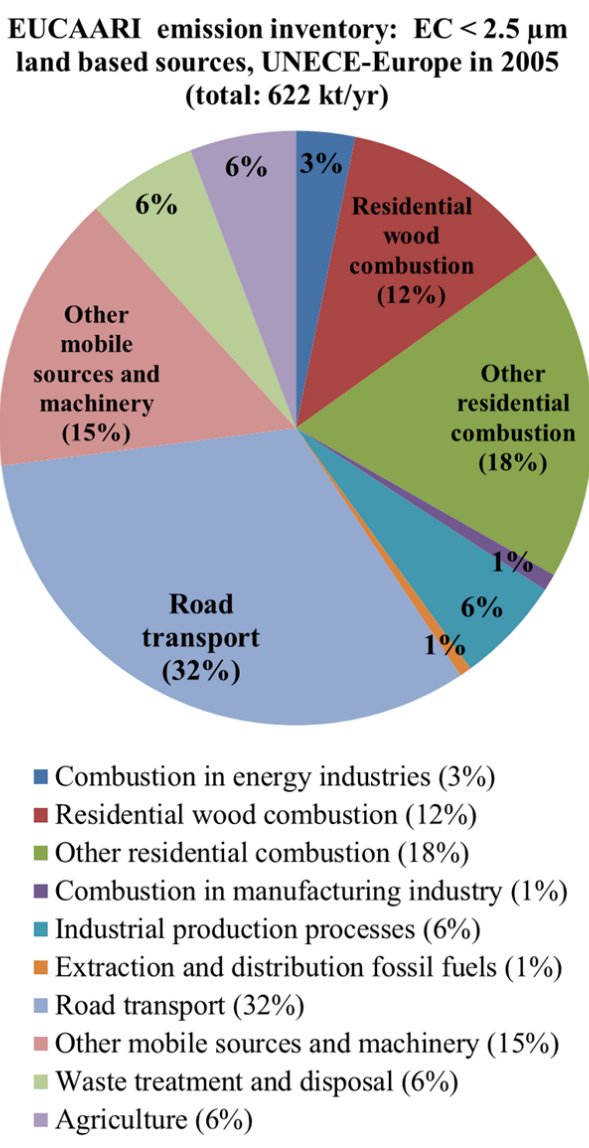

Fig. 8. Relative contribution from different source sectors to emissions of fine particulate elemental carbon $\left(\mathrm{EC}_{2.5}\right)$ in Europe in 2005 , as estimated in the emission inventory developed within the EUCAARI project.

with the Scandinavian countries, where different measurement protocols were used to estimate PM emissions from RWC. The measurement protocol used in Sweden only considers solid particles. The methodology consists of sampling of particles on a heated filter, through a probe, from undiluted flue gas in the chimney at gas temperatures of typically e.g. $160^{\circ} \mathrm{C}$ (German norms, VDI) or $120^{\circ} \mathrm{C}$ (US EPA; EPA Method 5; http://www.epa.gov/ttnemc01/methods/method5. html). The Norwegian method includes dilution of the sample in a dilution tunnel (DT) and thereby measures solid particles as well as condensable particles. (Haakonson and Kvingedal, 2001, and references therein; Sternhufvud et al., 2004). It will always give higher values than sampling only solid particles; however, considerable variation in methods is possible as dilution ratios, as well as cooling temperatures, may vary between methods. The Norwegian standard NS 3058-2 (Norsk Standard, 1994) describes sampling of filterable particles in a dilution tunnel with a filter holder gas temperature at e.g. $<35^{\circ} \mathrm{C}$. An overview of the different emission factor values and origin is given by Sternhufvud et al. (2004). 
Elemental carbon will be present in the solid particles only. Therefore, the fraction of EC present in PM from wood combustion depends on the sampling methodology; the absolute amount of EC is independent as solid particles are included in both methodologies. Thus, the Norwegian measurement protocol gives relatively large PM emissions, because contributions from all condensable organics are included, while the Swedish protocol gives relatively low PM emissions (all solid particles are included, but very little of the condensable organics are captured). Both measurement protocols are valid; however, they are incomparable and could be considered as being at the extreme ends of what could be defined as a representative measurement; one is tailored to include as much condensable fractions as possible, the other to measure almost only solid particles. Now when we apply a fixed $\mathrm{EC} / \mathrm{OC}$ fraction to the PM emissions from both countries, the result will be a large overestimation of EC in Norway because the PM included a large share of condensable organics. In the case of Sweden EC will be underestimated because the PM consisted mainly of solid particles to start with. So measurement-protocol-specific EC/OC fractions would be needed. If available, this would result in comparable EC data. It would not generate comparable condensable PM fractions as we cannot derive something that was not measured in the first place (there are no condensable organics in the Swedish protocol).

We also note that comparisons of model calculations, using the EUCAARI EC/OC emissions, and observations, including source-apportionment data, (e.g. Bergström et al., 2012; Genberg et al., 2011) have indicated that the inventory probably underestimates organic aerosol emissions from residential wood combustion substantially in large parts of Europe.

As a consequence of these findings, Denier van der Gon et al. (2013) created a bottom-up RWC emission inventory to get fully consistent and comparable data for different countries. A detailed description of the new inventory is given by Denier van der Gon et al. (2013), including evaluation of impacts on modelling of organic aerosol. Here we focus on the impact on EC emissions.

For most countries the EC emissions do not change as dramatically as the OC emissions in the new inventory. Total European $\mathrm{EC}_{2.5}$ emissions from residential wood combustion are approximately $26 \%$ higher in the new inventory compared to the EUCAARI emissions. This leads to about $5 \%$ higher total anthropogenic $\mathrm{EC}_{2.5}$ emissions in Europe with the new inventory. This is a relatively small change, but there are large differences between different countries. Moreover, the impact will be more pronounced during wintertime. Some of the largest changes occur in Norway, where the revised wood burning EC emissions in the new inventory are only about $1 / 3$ of the EUCAARI inventory, which leads to substantially lower total $\mathrm{EC}_{2.5}$ emissions in the updated inventory $(-46 \%)$. For neighbouring Sweden and Finland the new inventory has higher total $\mathrm{EC}_{2.5}$ emissions than the EU-
CAARI inventory $(+14 \%$ and $+31 \%$, respectively). The total $\mathrm{EC}_{2.5}$ emissions in the Nordic countries, from RWC and other sources, with the two different inventories, are shown in Fig. 9.

The difference in model EC output depending on the choice of inventory is illustrated in Figs. 10 and 11. For most areas, the new inventory gave similar modelled EC concentrations as the EUCAARI inventory. Relatively large EC increases ( $>20 \%$ as $6 \mathrm{yr}$ average) were seen in Austria and large parts of Romania. For Norway and Denmark modelled EC decreased with the new inventory; in parts of Norway, modelled total $\mathrm{EC}_{10}$ was reduced by more than $30 \%$.

At the eight sites included in this study, model calculations using the new inventory gave similar results for total EC to corresponding calculations that used the EUCAARI emissions (Fig. 11, Tables S3a and S3b). One reason for this is that the dominating source of EC is fossil fuel use, in most of Europe; another is that for most countries the EC emission estimates were similar in the two inventories. For emissions of organic aerosol the differences between the two inventories are much larger (Denier van der Gon et al., 2013).

Since only the residential wood burning emissions are different in the two inventories, the effect of the choice of inventory is greatest for the winter samples (for an illustration of the monthly variation of the EC emissions in the Scandinavian countries see Fig. S9). For all sites investigated except the Norwegian site Birkenes, the new RWC inventory increased the modelled EC concentrations. For example, at Melpitz the new inventory led to a median EC increase of $0.04 \mu \mathrm{g} \mathrm{m}^{-3}(8 \%)$ for the winter samples. At Birkenes, the effect of the RWC inventory was a mean decrease of 30$50 \%$ in wintertime EC concentration. For all stations the two different inventories gave essentially identical modelled EC concentrations during summer.

Although the total EC was similar for both emission inventories, larger differences can be seen when regarding only the $\mathrm{EC}$ originating from biomass burning $\left(\mathrm{EC}_{\mathrm{bb}}\right.$, including EC from both residential wood fuel combustion and open biomass fires). In Fig. 12 model-calculated EC from wood burning is compared to available source-apportionment data for five Scandinavian stations (10-90th percentiles, from source-apportionment based on tracers of wood burning emissions). For the two Norwegian sites Hurdal (rural) and Oslo (urban background) the new RWC inventory gave substantially lower $\mathrm{EC}_{\mathrm{bb}}$ than the EUCAARI inventory. The results were in much better agreement with the observations with the new inventory, especially for the rural site.

For the three Swedish sites, the new RWC inventory led to small increases in $\mathrm{EC}_{\mathrm{bb}}$ and better agreement with the observations at the rural sites Råö and Vavihill. For Vavihill the increase in $\mathrm{EC}_{\mathrm{bb}}$ was relatively small. However, Vavihill is located in southern Sweden and, because of the dominating south-westerly winds, influenced by Danish emissions (which decreased with TNO new RWC). 


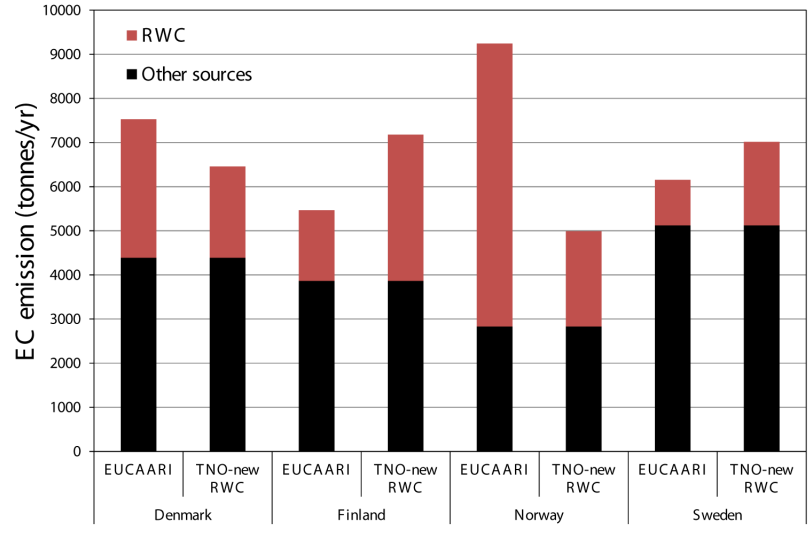

Fig. 9. Total emissions of $\mathrm{EC}_{2.5}$ in the Nordic countries (Denmark, Finland, Norway and Sweden) in the two different emission inventories (EUCAARI and TNO new RWC). Emissions from residential wood combustion are shown in red and the sum of all other sources in black. Unit: tonnes $\mathrm{yr}^{-1}$.
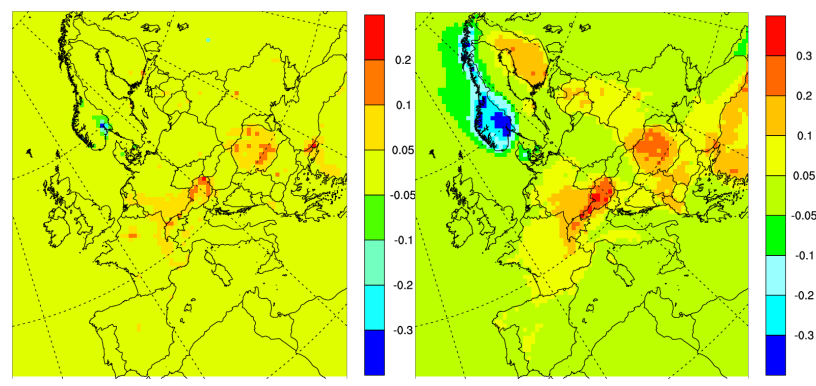

Fig. 10. Difference in modelled total $\mathrm{EC}_{10}$ concentrations (six-year mean, 2005-2010) between a model run using the new residential wood combustion emission inventory (TNO new RWC) and a run using the EUCAARI emission inventory. Left: the difference in total $\mathrm{EC}_{10}$ [TNO new RWC - EUCAARI] (unit: $\mu \mathrm{g} \mathrm{m}^{-3}$ ). Right: the relative difference in total $\mathrm{EC}_{10}$ [(TNO new RWCEUCAARI)/(EUCAARI)].

\subsection{EC from vegetation fires (agricultural and wildfires)}

The modelled long-term average contribution to $\mathrm{EC}_{10}$ from open-burning wildfires and agricultural fires to surface level concentrations of EC was below $3 \%$ at all the measurement sites included in this study (Fig. 3d). In the following we denote this source vegetation fires (and $\mathrm{EC}_{\text {vegfire }}$ ). At the three westernmost stations (Mace Head, Harwell and Overtoom) and Vavihill no significant $\mathrm{EC}_{\text {vegfire }}$ peaks were seen in the model results during the periods with EC measurements.

For Aspvreten (Fig. S3) there were a few occasions with vegetation fire contributions to model $\mathrm{EC}_{10}$, but the modelled $\mathrm{EC}_{\mathrm{vegfire}}$ concentrations were very low (the largest $\mathrm{EC}_{\mathrm{vegfire}}$ peak was ca. $0.1 \mu \mathrm{g} \mathrm{m}^{-3}$; the rest were below $0.05 \mu \mathrm{g} \mathrm{m}^{-3}$ ) and it is hard to draw any conclusions regarding the emission estimates from a comparison of these "episodes" with

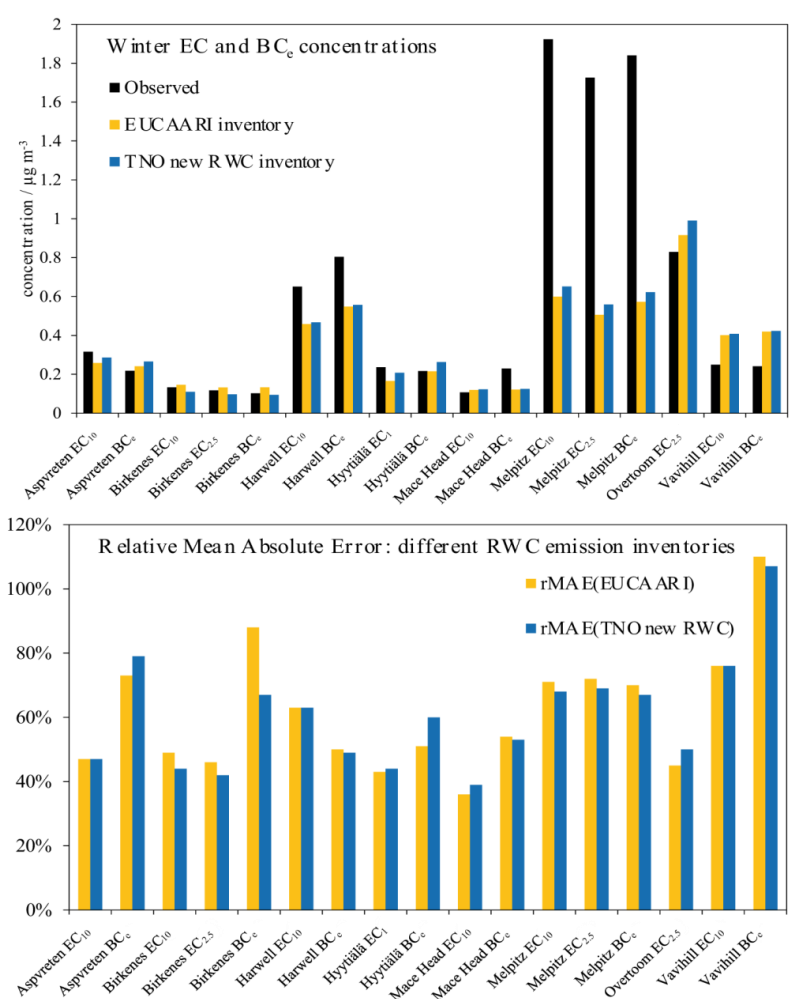

Fig. 11. Comparison of observed $\mathrm{EC}$, and $\mathrm{EC}$-equivalent $\mathrm{BC}_{\mathrm{e}}$, to modelled EC, using two different emission inventories for residential wood combustion. Data are from different periods for different stations (see Tables 1 and S3a and S3b). The upper diagram shows average $\mathrm{EC}$ or $\mathrm{BC}_{\mathrm{e}}$ concentrations during winter half-year periods (November-April): observed (black), model with EUCAARI emissions (orange), model with TNO new RWC emissions (blue); unit: $\mu \mathrm{g} \mathrm{m}^{-3}$. The lower diagram shows the relative mean absolute error (rMAE) for EUCAARI (orange) and TNO new RWC (blue); the rMAE is calculated as the MAE divided by the observed mean concentrations.

observed $\mathrm{EC}_{10}$. There were five observed $\mathrm{EC}_{10}$ peaks during 2010 that were substantially underestimated by the model, and some of these could possibly be due to missing vegetation fire emissions, but, as discussed in Sect. 3.3, other sources are perhaps more likely.

For Hyytiälä at least three observed $\mathrm{EC}_{1}$ peaks (EC in particles with an aerodynamic diameter less than $1 \mu \mathrm{m}$ ) were clearly underestimated by the model (Fig. S7). The largest observed EC peak $\left(1.5 \mu \mathrm{g} \mathrm{m}^{-3}\right.$; underestimated by a factor of three), occurred in late March 2007; based on the model results, it seems to have included substantial contributions from vegetation fires, RWC and fossil sources. The peak was relatively broad, with elevated EC concentrations for about a week. The model $\mathrm{EC}_{\text {vegfire }}$ correlates best with the observations, with a maximum on $29 \mathrm{March}$; the anthropogenic sources peaked the day before. This could indicate that the $\mathrm{EC}_{\text {vegfire }}$ was underestimated rather much at Hyytiälä, at least 


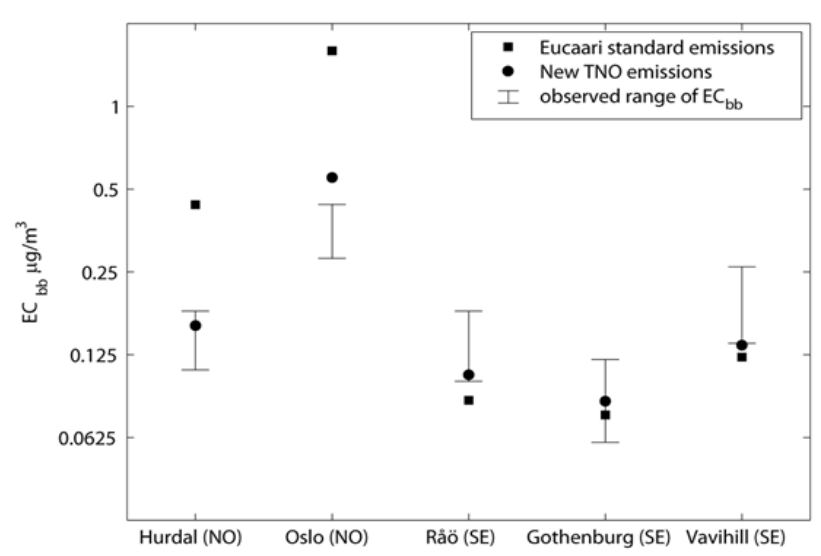

Fig. 12. Biomass burning $\mathrm{EC}\left(\mathrm{EC}_{\mathrm{bb}}\right)$ from wintertime sourceapportionment studies in Scandinavia (Yttri et al., 2011; Szidat et al., 2009; Genberg et al., 2011) compared to model calculations using different emission inventories. Observed $\mathrm{EC}_{\mathrm{bb}}$ bars represent 10th and 90th percentiles. Note the logarithmic scale on the $y$ axis.

near the end of this episode, potentially making up a substantial part of the missing EC.

Saarnio et al. (2010) measured levoglucosan (and other monosaccharide anhydrides) at Hyytiälä during the period 28 March-27 April 2007 (i.e, the measurements started in the middle of the major EC peak at the site). The measured levoglucosan concentrations are compared to the modelled EC from non-fossil sources (RWC + vegetation fires, i.e. $\mathrm{EC}_{\mathrm{bb}}$ ) in Fig. 13. Levoglucosan concentrations are shown as an interval where the concentrations are multiplied with 0.3 and 5.6, to be comparable with $\mathrm{EC}_{\mathrm{bb}}$ (Genberg et al., 2011). The first observed levoglucosan peak confirms that there were major contributions from wood fires during the largest EC episode, as indicated by the model results. This was also corroborated by an increased Ångström coefficient. At the time of the first levoglucosan sampling, the model overestimated the wood burning contribution to EC (at least when using the updated RWC emission inventory), but for the following two days the $\mathrm{EC}_{\mathrm{bb}}$ tends to be underestimated. However, the underestimation of the total EC was much larger than of the $\mathrm{EC}_{\mathrm{bb}}$, which means that fossil $\mathrm{EC}$ must also have been substantially underestimated by the model during this period. In fact, the $\mathrm{EC}_{\text {fossil }}$ was likely more underestimated than the $\mathrm{EC}_{\mathrm{bb}}\left(\mathrm{EC}_{\text {fossil }}\right.$ was underestimated by at least 0.4 to $0.5 \mu \mathrm{g} \mathrm{m}^{-3}$ and $\mathrm{EC}_{\mathrm{bb}}$ by max. 0.2 to $0.3 \mu \mathrm{g} \mathrm{m}^{-3}$, as averages for the three days with peak observations).

Apart from these first three levoglucosan samples the model performed relatively well compared to the observations, with one major exception: on the 7 April 2007 a high levoglucosan concentration ( $79 \mathrm{ng} \mathrm{m}^{-3}$ ) was observed, but the model results showed very low $\mathrm{EC}_{\mathrm{bb}}$ concentrations. At the same time, the Ångström coefficient increased, indicating an increased contribution from biomass burning, although the observed $\mathrm{BC}$ concentration was low. This could indicate

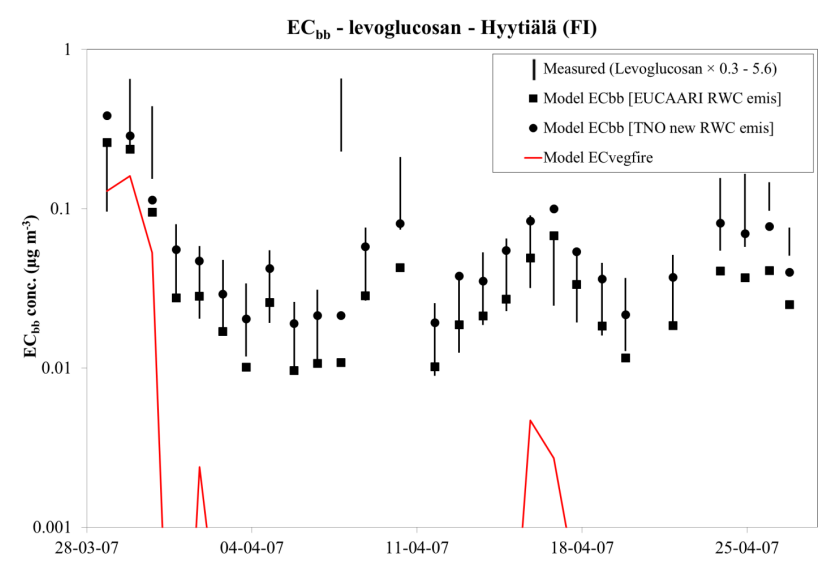

Fig. 13. Levoglucosan concentration and modelled EC from biomass burning $\left(\mathrm{EC}_{\mathrm{bb}}=\mathrm{EC}\right.$ from open burning of biomass $+\mathrm{EC}$ from residential wood combustion) at Hyytiälä in April 2007. The levoglucosan concentrations (vertical lines) are scaled by factors of 0.3 to 5.6 to be comparable to $\mathrm{EC}_{\mathrm{bb}}$ (see text). Model $\mathrm{EC}_{\mathrm{bb}}$ are from two different model setups, one using the EUCAARI emissions for RWC (squares) and one using the new TNO inventory for RWC (dots). The model-calculated EC from the open burning of biomass is also shown $\left(\mathrm{EC}_{\mathrm{vegfire}}\right.$, red line; values $<0.001 \mu \mathrm{g} \mathrm{m}^{-3}$ are not shown). Unit: $\mu \mathrm{g} \mathrm{m}^{-3}$.

a vegetation fire that was not included in the emission inventory, but, since the 7 April 2007 was Easter Saturday, it is more likely that the peak was due to local/nearby burning, either traditional Easter Fires or other residential combustion (e.g. sauna stoves). The following two samples (8 and 9 April) also showed elevated levoglucosan levels, which the model captured, at least to some degree; but all model $\mathrm{EC}_{\mathrm{bb}}$ came from RWC during this period - no $\mathrm{EC}_{\text {vegfire }}$ contributions were seen.

The only other significant modelled vegetation fire peak at Hyytiälä (during the EC measurement period) occurred on 13 August 2007, which also corresponded to a minor peak in the observed $\mathrm{EC}_{1}$. The model underestimated the observed EC by $26 \%$ (unless EC ageing was turned off) but we cannot determine if this was due to underestimation of the fossil or vegetation fire $\mathrm{EC}$ or both.

For Melpitz (Fig. S1), even the highest model $\mathrm{EC}_{\text {vegfire }}$ concentrations $\left(0.2-0.9 \mu \mathrm{g} \mathrm{m}^{-3}\right)$ were low compared to the very high observed total EC. Most of the time, the modelled fossil $\mathrm{EC}$ was much higher than the $\mathrm{EC}_{\text {vegfire }}$ component, making evaluation of the vegetation fire emissions difficult. Nevertheless, there was one very interesting $\mathrm{EC}_{\text {vegfire }}$ peak at Melpitz on 5-9 May 2006. This was the result of agricultural fires in eastern Europe (Stohl et al., 2007). Model $\mathrm{EC}_{\mathrm{vegfire}}$ peaked on 6 May with approximately $0.9 \mu \mathrm{g} \mathrm{m}^{-3}$. The modelled fossil $\mathrm{EC}_{2.5}$ on the same day was below $0.3 \mu \mathrm{g} \mathrm{m}^{-3}$ and RWC was insignificant. The observed $\mathrm{EC}_{2.5}$ was very high $\left(9 \mu \mathrm{g} \mathrm{m}^{-3}\right)$; the model underestimated total $\mathrm{EC}_{2.5}$ by a factor of seven. For a single episode though, it is not possible to 
distinguish where problems are due to underestimated fire emissions or the modelled dispersion. Even the long-term average $\mathrm{EC}_{2.5}$ was underestimated by more than a factor of three at Melpitz, which indicates severe problems also with the fossil sources (as discussed in Sect. 3.3). A similar episode with potential large impact from vegetation fires occurred on 1-2 April 2007, when observed $\mathrm{EC}_{2.5}$ peaked at $6.7 \mu \mathrm{g} \mathrm{m}^{-3}$; the model underestimated this by $90 \%$ and the peak coincided with a vegetation fire episode in the model.

At Birkenes (Fig. S4) there were four observed EC peaks that corresponded to simultaneous modelled $\mathrm{EC}_{\text {vegfire }}$ peaks during the period 2005-2010. The highest modelled $\mathrm{EC}_{\text {vegfire }}$ was found during the period 26 April-15 May 2006 with a peak value of about $0.2 \mu \mathrm{g} \mathrm{EC} \mathrm{m}{ }^{-3}$, as an average for the 6-day sampling period 3-8 May. This is the same agricultural fire episode as was observed at Melpitz. Interestingly, the modelled total $\mathrm{EC}_{2.5}$ was in good agreement with the observations from the middle of March until the middle of July 2006, with only a few marked exceptions when the model overpredicted EC severely because of too-high modelled fossil EC. Thus, some fossil EC source(s) seem clearly overestimated in the model. The modelled EC peak on 26 September 2006 also contained some $\mathrm{EC}_{\text {vegfire }}$ but even more fossil $\mathrm{EC}$, and the total $\mathrm{EC}$ was overestimated also for this period.

The largest total $\mathrm{EC}_{2.5}$ peak (11 October 2005) was underestimated by approximately $25 \%$ by the model. All model components peaked at the same time (fossil, RWC and vegetation fires), so with only EC observations it is impossible to determine which of the emission sources was most likely underestimated.

The second-highest observed EC peak occurred over a somewhat longer time period, 21 March-3 April, 2007 (three EC samples). This peak was clearly underestimated by the model except for the first 6-day sample. The first sample was dominated by $\mathrm{EC}_{\mathrm{vegfire}}$ in the model, while fossil $\mathrm{EC}$ was the most abundant fraction during the following two periods. This could be an indication that the fossil EC emissions were underestimated or that this particular open fire event was of too-short duration in the emission inventory, or that there were too-large deposition losses in the model.

There was a limited number of obvious vegetation fire events at the sites included in the present study (during the EC measurement periods), and the modelled contribution to EC from this source was usually relatively small, compared to EC from other sources. It is not possible to determine whether it is more realistic to treat the $\mathrm{EC}_{\text {vegfire }}$ emissions as hydrophilic or hydrophobic based on the results from this study; the difference in modelled EC between the two alternatives is often very small.

\subsection{Modelled ageing of EC}

Three different assumptions regarding the atmospheric ageing and wet deposition of EC were compared, FRESH (all EC hydrophobic), STD (standard ageing assumptions) and
AGED (all EC considered internally mixed and hygroscopic when emitted). The new RWC emissions were used for all three ageing scenarios.

Assuming all EC as hydrophobic (FRESH) led to higher EC concentrations all over Europe (Fig. S10). The absolute difference was largest in the high-emission areas, but the relative importance of the ageing was largest at remote locations where the EC is mainly due to long-range transport.

Comparing modelled EC to observations (Fig. 6, Tables S2a, S2b) shows that the FRESH model overestimated EC at most of the more remote locations, as expected. For Melpitz and Harwell the model underestimated EC even without ageing, which may indicate underestimated emissions or (relatively) local emissions influencing the measurements, making them unrepresentative on the $50 \mathrm{~km} \times 50 \mathrm{~km}$ grid resolution of the model. For the EC comparison the correlation coefficients were similar with the different ageing schemes (see Table S2a).

Differences between the AGED and STD model version were very small - similar to what was found by Tsyro et al. (2007). This is due to the relatively rapid ageing rate used in the model. For most sites the bias, MAE and correlation were slightly better with the STD model compared to the AGED version.

\section{Conclusions}

The EMEP MSC-W model is an important tool for policy makers. Thus it is essential to know how well the model can reproduce the measured concentrations of different air pollutants. This study shows that the combination of the EMEP model with recently developed emission inventories for EC performs generally well when compared to measurements of (long-term average) EC concentrations at regional background sites in the northern part of Europe.

In the present study, EC and $\mathrm{BC}$ were measured using eight different methods or protocols which induce uncertainties into the analysis. To some extent, the variations observed are probably due to differences between the measurement techniques. One example is the VDI method, used at Melpitz, which provides higher EC concentrations compared to the thermal-optical methods. This propagates into the sitespecific mass absorption cross section $\left(\mathrm{MAC}_{\mathrm{e}}\right)$ values as well. Harmonizing the measurement techniques for both EC and $\mathrm{BC}$ is an important step in order to obtain comparable results for these variables across Europe.

To make the comparison between EC and BC less method dependent, the BC values were normalized with simultaneous EC measurements. This method was fairly successful for most stations, but the correction factors varied a lot between the different stations, and the station-specific $\mathrm{MAC}_{\mathrm{e}}$ values varied from 5.5 to $46 \mathrm{~m}^{2} \mathrm{~g}^{-1}$. Clearly, correcting BC data from different stations using the same MAC values for all sites is not meaningful. Although having advantages in 
terms of high temporal resolution, the results presented here suggest that optical methods are inappropriate for determining ambient EC mass, without a secondary method validating the measurement. This makes such data difficult to use for chemical transport model evaluations.

Residential wood combustion is an important source of EC in large parts of Europe. The new emission inventory for EC from RWC, presented in this study, improved model results for source-apportioned EC from wood burning, compared to the EUCAARI inventory, for all stations investigated. The present study investigated a limited set of stations in Sweden, Norway and Finland, and further comparisons are needed to fully evaluate the performance over other European regions. Noteworthy is that the new RWC emission inventory led to substantial improvements in the modelled EC from wood burning in Norway, which is the country with the largest change in emissions compared to the earlier estimates.

Open biomass burning is an important source of EC in the atmosphere during fire episodes. For the sites included in this study (located in northern/western/central Europe) the longterm average modelled contributions from open biomass fires to ground level concentrations of EC were, however, very small $\left(<3 \%\right.$ of the model total $\left.\mathrm{EC}_{10}\right)$. A few open biomass fire episodes were detected at some of the sites, but - due to the limited availability of source-apportionment data (tracers of wood burning) and the comparably large emissions of fossil EC often affecting the sites at the same time as the fire episodes - it is very difficult to determine how well the $\mathrm{EC}_{\mathrm{veg}}$ ire is modelled. For some of the episodes the modelled $\mathrm{EC}_{\text {vegfire }}$ was likely underestimated, which may indicate some problems with emissions during these fires (underestimated emissions or overestimated effective emission heights) or too-efficient scavenging of the $\mathrm{EC}_{\mathrm{vegfire}}$ in the model.

Evaluation of model results is difficult, due to limited and uncertain source apportionments of biomass-burning-related particles. The use of levoglucosan could be complemented by other analyses such as ${ }^{14} \mathrm{C}$ measurements on $\mathrm{EC}$, and measurements of potassium. More observations of tracers of wood burning are needed in order to test and improve both EC models and emission inventories for RWC and open biomass burning.

We have examined the sensitivity of the model to assumptions concerning the transformation of initially hydrophobic EC to hydrophilic particles, as the latter can be efficiently scavenged by precipitation. Treating EC as hydrophobic, with no ageing, led to too-high EC concentrations at most sites. The ageing parameterization used in the EMEP MSC-W model led to better agreement for average EC concentrations, at least for the less polluted sites. Although it is difficult to draw firm conclusions regarding the ageing rates, based on the data presented in the present study, we find that results for the majority of sites studied here indicate that the ageing scheme may lead to too-rapid ageing of EC. The scheme was originally constructed to simulate EC ageing in polluted environments, and it may be less realistic for cleaner parts of Europe.

Future plans involve work on investigating the RWC emissions contribution to organic aerosol in Europe, and further detailed comparisons of the EMEP MSC-W model to measurements that include tracers of wood burning, in an effort to improve the modelling of both RWC and the impact of open biomass burning.

\section{Supplementary material related to this article is available online at: http://www.atmos-chem-phys.net/13/ 8719/2013/acp-13-8719-2013-supplement.pdf.}

Acknowledgements. The research leading to these results has received funding from the European Union Seventh Framework Programme (FP7/2007-2013) under grant agreement no. 262254 ACTRIS, the 6th Framework programme (EUCAARI, no. 34684), the Swedish research council Formas and the Swedish Clean Air Research Programme (SCARP). This work is also a contribution to the strategic research area MERGE - ModElling the Regional and Global Earth system.

Measurements of EC and BC were acquired primarily from the EBAS database (http://ebas.nilu.no). Special thanks to Dave de Jonge for EC data from Overtoom, Peter Tunved for EC data from Aspvreten, Thomas Tuch for BC data from Melpitz, Markku Kulmala for BC data from Hyytiälä and Petri Keronen (Univ. Helsinki) for $\mathrm{NO}_{\mathrm{x}}$ data from Hyytiälä.

Edited by: V.-M. Kerminen

\section{References}

Aas, W., Tsyro, S., Bieber, E., Bergström, R., Ceburnis, D., Ellermann, T., Fagerli, H., Frölich, M., Gehrig, R., Makkonen, U., Nemitz, E., Otjes, R., Perez, N., Perrino, C., Prévôt, A. S. H., Putaud, J.-P., Simpson, D., Spindler, G., Vana, M., and Yttri, K. E.: Lessons learnt from the first EMEP intensive measurement periods, Atmos. Chem. Phys., 12, 8073-8094, doi:10.5194/acp12-8073-2012, 2012.

Andreae, M. O. and Gelencsér, A.: Black carbon or brown carbon? The nature of light-absorbing carbonaceous aerosols, Atmos. Chem. Phys., 6, 3131-3148, doi:10.5194/acp-6-3131-2006, 2006.

Arnott, W. P., Moosmüller, H., Rogers, C. F., Jin, T., and Bruch, R.: Photoacoustic spectrometer for measuring light absorption by aerosol: instrument description, Atmos. Environ., 33, 28452852, doi:10.1016/s1352-2310(98)00361-6, 1999.

Arnott, W. P., Moosmüller, H., Sheridan, P. J., Ogren, J. A., Raspet, R., Slaton, W. V., Hand, J. L., Kreidenweis, S. M., and Collett Jr., J. L.: Photoacoustic and filter-based ambient aerosol light absorption measurements: Instrument comparisons and the role of relative humidity, J. Geophys. Res., 108, 4034, doi:10.1029/2002JD002165, 2003. 
Aurela, M., Saarikoski, S., Timonen, H., Aalto, P., Keronen, P., Saarnio, K., Teinilä, K., Kulmala, M., and Hillamo, R.: Carbonaceous aerosol at a forested and an urban background sites in Southern Finland, Atmos. Environ., 45, 1394-1401, doi:10.1016/j.atmosenv.2010.12.039, 2011.

Benedictow, A.: Documentation and verification of the 1999 PARLAM-PS meteorological fields used as input for Eulerian EMEP model, Tech. rep., The Norwegian Meteorological Institute, Oslo , 111, 2003.

Berge, E. and Jakobsen, H. A.: A regional scale multi-layer model for the calculation of long-term transport and deposition of air pollution in Europe, Tellus B, 50, 205-223, 1998.

Bergström, R., Denier van der Gon, H. A. C., Prévôt, A. S. H., Yttri, K. E., and Simpson, D.: Modelling of organic aerosols over Europe (2002-2007) using a volatility basis set (VBS) framework: application of different assumptions regarding the formation of secondary organic aerosol, Atmos. Chem. Phys., 12, 8499-8527, doi:10.5194/acp-12-8499-2012, 2012.

Bessagnet, B., Menut, L., Curci, G., Hodzic, A., Guillaume, B., Liousse, C., Moukhtar, S., Pun, B., Seigneur, C., and Schulz, M.: Regional modeling of carbonaceous aerosols over Europe - focus on secondary organic aerosols, J. Atmos. Chem., 61, 175-202, doi:10.1007/s10874-009-9129-2, 2008.

Birch, M. E. and Cary, R. A.: Elemental carbon-based method for monitoring occupational exposures to particulate diesel exhaust, Aerosol. Sci. Tech., 25, 221-241, 1996.

Bjørge, D. and Skålin, R.: PARLAM the parallel HIRLAM version at DNMI, Research Report 27, The Norwegian Meteorological Institute, Oslo, Norway, 1995.

Bond, T. C. and Bergstrom, R. W.: Light Absorption by Carbonaceous Particles: An Investigative Review, Aerosol. Sci. Tech., 40, 27-67, doi:10.1080/02786820500421521, 2006.

Bond, T. C., Anderson, T. L., and Campbell, D.: Calibration and Intercomparison of Filter-Based Measurements of Visible Light Absorption by Aerosols, Aerosol. Sci. Tech., 30, 582-600, doi:10.1080/027868299304435, 1999.

Bond, T. C., Doherty, S. J., Fahey, D. W., Forster, P. M., Berntsen, T., DeAngelo, B. J., Flanner, M. G., Ghan, S., Kärcher, B., Koch, D., Kinne, S., Kondo, Y., Quinn, P. K., Sarofim, M. C., Schultz, M. G., Schulz, M., Venkataraman, C., Zhang, H., Zhang, S., Bellouin, N., Guttikunda, S. K., Hopke, P. K., Jacobson, M. Z., Kaiser, J. W., Klimont, Z., Lohmann, U., Schwarz, J. P., Shindell, D., Storelvmo, T., Warren, S. G., and Zender, C. S.: Bounding the role of black carbon in the climate system: A scientific assessment, J. Geophys. Res.-Atmos., 118, 5380-5552, doi:10.1002/jgrd.50171, 2013.

Cavalli, F., Viana, M., Yttri, K. E., Genberg, J., and Putaud, J.-P.: Toward a standardised thermal-optical protocol for measuring atmospheric organic and elemental carbon: the EUSAAR protocol, Atmos. Meas. Tech., 3, 79-89, doi:10.5194/amt-3-79-2010, 2010

Cheng, Y., He, K.-B., Zheng, M., Duan, F.-K., Du, Z.-Y., Ma, Y.L., Tan, J.-H., Yang, F.-M., Liu, J.-M., Zhang, X.-L., Weber, R. J., Bergin, M. H., and Russell, A. G.: Mass absorption efficiency of elemental carbon and water-soluble organic carbon in Beijing, China, Atmos. Chem. Phys., 11, 11497-11510, doi:10.5194/acp11-11497-2011, 2011.

Cooke, W. F., Liousse, C., Cachier, H., and Feichter, J.: Construction of a $1^{\circ} \times 1^{\circ}$ fossil fuel emission data set for carbonaceous aerosol and implementation in the ECHAM 4 model, J. Geophys. Res., 104, 22137-22162, doi:10.1029/1999JD900187, 1999.

Croft, B., Lohmann, U., and von Salzen, K.: Black carbon ageing in the Canadian Centre for Climate modelling and analysis atmospheric general circulation model, Atmos. Chem. Phys., 5, 19311949, doi:10.5194/acp-5-1931-2005, 2005.

Denier van der Gon, H., Visschedijk, A., Droge, R., Mulder, M., Johansson, C., and Klimont, Z.: A high resolution emission inventory of particulate elemental carbon and organic carbon for Europe in 2005, 7th International Conference on Air Quality Science and Application (Air Quality 2009), Istanbul, 2009.

Denier van der Gon, H., Visschedijk, A., Pandis, S., Fountoukis, C., Bergström, R., Simpson, D., and Johansson, C.: Particulate emissions from residential wood combustion in Europe - revised estimates and an evaluation, in preparation, 2013.

Donahue, N. M., Robinson, A. L., Stanier, C. O., and Pandis, S. N.: Coupled partitioning, dilution, and chemical aging of semivolatile organics, Environ. Sci. Technol., 40, 2635-2643, doi:10.1021/es052297c, 2006.

Engelhart, G. J., Hennigan, C. J., Miracolo, M. A., Robinson, A. L., and Pandis, S. N.: Cloud condensation nuclei activity of fresh primary and aged biomass burning aerosol, Atmos. Chem. Phys., 12, 7285-7293, doi:10.5194/acp-12-7285-2012, 2012.

Fagerli, H. and Aas, W.: Trends of nitrogen in air and precipitation: Model results and observations at EMEP sites in Europe, 1980-2003, Environ. Pollut., 154, 448-461, doi:10.1016/j.envpol.2008.01.024, 2008.

Forster, P., Ramaswamy, V., Artaxo, P., Berntsen, T., Betts, R., Fahey, D. W., Haywood, J., Lean, J., Lowe, D. C., Myhre, G., Nganga, J., Prinn, R., Raga, G., Schulz, M., and Van Dorland, R.: Climate Change 2007:The Physical Science Basis. Contribution of Working Group I to the Fourth Assessment Report of the Intergovernmental Panel on Climate Change, IPCC, Cambridge University Press, Cambridge, United Kingdom and New York, NY, USA, 2007.

Fowler, D., Pilegaard, K., Sutton, M., Ambus, P., Raivonen, M., Duyzer, J., Simpson, D., Fagerli, H., Fuzzi, S., Schjoerring, J., Granier, C., Neftel, A., Isaksen, I., Laj, P., Maione, M., Monks, P., Burkhardt, J., Daemmgen, U., Neirynck, J., Personne, E., Wichink-Kruit, R., Butterbach-Bahl, K., Flechard, C., Tuovinen, J., Coyle, M., Gerosa, G., Loubet, B., Altimir, N., Gruenhage, L., Ammann, C., Cieslik, S., Paoletti, E., Mikkelsen, T., Ro-Poulsen, H., Cellier, P., Cape, J., Horváth, L., Loreto, F., Niinemets, Ü., Palmer, P., Rinne, J., Misztal, P., Nemitz, E., Nilsson, D., Pryor, S., Gallagher, M., Vesala, T., Skiba, U., Brüeggemann, N., Zechmeister-Boltenstern, S., Williams, J., O’Dowd, C., Facchini, M., de Leeuw, G., Flossman, A., Chaumerliac, N., and Erisman, J.: Atmospheric composition change: Ecosystems-Atmosphere interactions, Atmos. Environ., 43, 5193-5267, 2009.

Genberg, J., Hyder, M., Stenström, K., Bergström, R., Simpson, D., Fors, E. O., Jönsson, J. Å., and Swietlicki, E.: Source apportionment of carbonaceous aerosol in southern Sweden, Atmos. Chem. Phys., 11, 11387-11400, doi:10.5194/acp-1111387-2011, 2011.

Gnauk, T., Müller, K., Brüggemann, E., Birmili, W., Weinhold, K., van Pinxteren, D., Löschau, G., Spindler, G., and Herrmann, H.: A study to discriminate local, urban and regional source contributions to the particulate matter concentrations in the city of Dresden, Germany, J. Atmos. Chem., 68, 199-231, 
doi:10.1007/s10874-012-9216-7, 2011.

Granier, C., Bessagnet, B., Bond, T., D’Angiola, A., van der Gon, H. D., Frost, G. J., Heil, A., Kaiser, J. W., Kinne, S., Klimont, Z., Kloster, S., Lamarque, J.-F., Liousse, C., Masui, T., Meleux, F., Mieville, A., Ohara, T., Raut, J.-C., Riahi, K., Schultz, M. G., Smith, S. J., Thompson, A., van Aardenne, J., van der Werf, G. R., and van Vuuren, D. P.: Evolution of anthropogenic and biomass burning emissions of air pollutants at global and regional scales during the 1980-2010 period, Climatic Change, 109, 163-190, 2011.

Haakonson, G. and Kvingedal, E.: Utslipp til luft fra vedfyring i Norge. Utslippsfaktorer, ildstedsbestand og fyringsvaner. Statistisk sentralbyrå - Statistics Norway, 2001/36, available at: http:// www.ssb.no/a/publikasjoner/pdf/rapp_200136/rapp_200136.pdf, 2001.

Hadley, O. L. and Kirchstetter, T. W.: Black-carbon reduction of snow albedo, Nature Clim. Change, 2, 437-440, doi:10.1038/nclimate1433, 2012.

Hansen, A. D. A., Rosen, H., and Novakov, T.: Real-time measurement of the absorption coefficient of aerosol particles, Appl. Opt., 21, 3060-3062, 1982.

Hansen, J. and Nazarenko, L.: Soot climate forcing via snow and ice albedos, Proc. Natl Acad. Sci. USA, 101, 423-428, 2004.

Henne, S., Brunner, D., Folini, D., Solberg, S., Klausen, J., and Buchmann, B.: Assessment of parameters describing representativeness of air quality in-situ measurement sites, Atmos. Chem. Phys., 10, 3561-3581, doi:10.5194/acp-10-3561-2010, 2010.

Herrmann, H., Brüggemann, E., Franck, U., Gnauk, T., Löschau, G., Müller, K., Plewka, A., and Spindler, G.: A source study of PM in Saxony by size-segregated characterisation, J. Atmos. Chem., 55, 103-130, doi:10.1007/s10874-006-9029-7, 2006.

Janssen, N. A. H., Hoek, G., Simic-Lawson, M., Fischer, P., van Bree, L., ten Brink, H., Keuken, M., Atkinson, R. W., Anderson, H. R., Brunekreef, B., and Cassee, F. R.: Black Carbon as an Additional Indicator of the Adverse Health Effects of Airborne Particles Compared with $\mathrm{PM}_{10}$ and $\mathrm{PM}_{2.5}$, Environ. Health Perspect., 119, 1691-1699, doi:10.1289/ehp.1003369, 2011.

Jennings, S. G., Kleefeld, C., O’Dowd, C. D., Junker, C., Spain, T. G., O'Brien, P., Roddy, A. F., and O'Connor, T. C.: Mace head Atmospheric Research Station - characterization of aerosol radiative parameters, Boreal Environ. Res., 8, 303-314, 2003.

Johnson, R. L., Shah, J. J., Cary, R. A., and Huntzicker, J. J.: An Automated Thermal-Optical Method for the Analysis of Carbonaceous Aerosol, in: Atmospheric Aerosol, ACS Symposium Series, edited by: Macias, E. S. and Hopke, P. K., 167, American Chemical Society, 223-233, Plenum Press, New York, 1981.

Jonson, J. E., Simpson, D., Fagerli, H., and Solberg, S.: Can we explain the trends in European ozone levels?, Atmos. Chem. Phys., 6, 51-66, doi:10.5194/acp-6-51-2006, 2006.

Kirchstetter, T. W., Novakov, T., and Hobbs, P. V.: Evidence that the spectral dependence of light absorption by aerosols is affected by organic carbon, J. Geophys. Res., 109, D21208, doi:10.1029/2004JD004999, 2004.

Koch, D. and Del Genio, A. D.: Black carbon semi-direct effects on cloud cover: review and synthesis, Atmos. Chem. Phys., 10, 7685-7696, doi:10.5194/acp-10-7685-2010, 2010.

Koch, D., Schulz, M., Kinne, S., McNaughton, C., Spackman, J. R., Balkanski, Y., Bauer, S., Berntsen, T., Bond, T. C., Boucher, O., Chin, M., Clarke, A., De Luca, N., Dentener, F., Diehl, T.,
Dubovik, O., Easter, R., Fahey, D. W., Feichter, J., Fillmore, D., Freitag, S., Ghan, S., Ginoux, P., Gong, S., Horowitz, L., Iversen, T., Kirkevåg, A., Klimont, Z., Kondo, Y., Krol, M., Liu, X., Miller, R., Montanaro, V., Moteki, N., Myhre, G., Penner, J. E., Perlwitz, J., Pitari, G., Reddy, S., Sahu, L., Sakamoto, H., Schuster, G., Schwarz, J. P., Seland, Ø., Stier, P., Takegawa, N., Takemura, T., Textor, C., van Aardenne, J. A., and Zhao, Y.: Evaluation of black carbon estimations in global aerosol models, Atmos. Chem. Phys., 9, 9001-9026, doi:10.5194/acp-9-9001-2009, 2009.

Kulmala, M., Asmi, A., Lappalainen, H. K., Baltensperger, U., Brenguier, J.-L., Facchini, M. C., Hansson, H.-C., Hov, Ø., O'Dowd, C. D., Pöschl, U., Wiedensohler, A., Boers, R., Boucher, O., de Leeuw, G., Denier van der Gon, H. A. C., Feichter, J., Krejci, R., Laj, P., Lihavainen, H., Lohmann, U., McFiggans, G., Mentel, T., Pilinis, C., Riipinen, I., Schulz, M., Stohl, A., Swietlicki, E., Vignati, E., Alves, C., Amann, M., Ammann, M., Arabas, S., Artaxo, P., Baars, H., Beddows, D. C. S., Bergström, R., Beukes, J. P., Bilde, M., Burkhart, J. F., Canonaco, F., Clegg, S. L., Coe, H., Crumeyrolle, S., D’Anna, B., Decesari, S., Gilardoni, S., Fischer, M., Fjaeraa, A. M., Fountoukis, C., George, C., Gomes, L., Halloran, P., Hamburger, T., Harrison, R. M., Herrmann, H., Hoffmann, T., Hoose, C., Hu, M., Hyvärinen, A., Hõrrak, U., Iinuma, Y., Iversen, T., Josipovic, M., Kanakidou, M., Kiendler-Scharr, A., Kirkevåg, A., Kiss, G., Klimont, Z., Kolmonen, P., Komppula, M., Kristjánsson, J.-E., Laakso, L., Laaksonen, A., Labonnote, L., Lanz, V. A., Lehtinen, K. E. J., Rizzo, L. V., Makkonen, R., Manninen, H. E., McMeeking, G., Merikanto, J., Minikin, A., Mirme, S., Morgan, W. T., Nemitz, E., O’Donnell, D., Panwar, T. S., Pawlowska, H., Petzold, A., Pienaar, J. J., Pio, C., Plass-Duelmer, C., Prévôt, A. S. H., Pryor, S., Reddington, C. L., Roberts, G., Rosenfeld, D., Schwarz, J., Seland, Ø., Sellegri, K., Shen, X. J., Shiraiwa, M., Siebert, H., Sierau, B., Simpson, D., Sun, J. Y., Topping, D., Tunved, P., Vaattovaara, P., Vakkari, V., Veefkind, J. P., Visschedijk, A., Vuollekoski, H., Vuolo, R., Wehner, B., Wildt, J., Woodward, S., Worsnop, D. R., van Zadelhoff, G.-J., Zardini, A. A., Zhang, K., van Zyl, P. G., Kerminen, V.-M., S Carslaw, K., and Pandis, S. N.: General overview: European Integrated project on Aerosol Cloud Climate and Air Quality interactions (EUCAARI) - integrating aerosol research from nano to global scales, Atmos. Chem. Phys., 11, 13061-13143, doi:10.5194/acp11-13061-2011, 2011.

Lanki, T., de Hartog, J. J., Heinrich, J., Hoek, G., Janssen, N. A. H., Peters, A., Stölzel, M., Timonen, K. L., Vallius, M., Vanninen, E., and Pekkanen, J.: Can We Identify Sources of Fine Particles Responsible for Exercise Induced Ischemia on Days with Elevated Air Pollution? The Ultra Study, Environ. Health Persp., 114, 655-660, doi:10.1289/ehp.8578, 2006.

Legrand, M. and Puxbaum, H.: Summary of the CARBOSOL project: Present and retrospective state of organic versus inorganic aerosol over Europe, J. Geophys. Res.-Atmos., 112, D23S01, doi:10.1029/2006jd008271, 2007.

Liousse, C., Cachier, H., and Jennings, S. G.: Optical and thermal measurements of black carbon contents in different environments; variation of the specific attenuation cross-section, Atmos. Environ., 27A, 1203-1211, doi:10.1016/0960-1686(93)90246U, 1993. 
Mareckova, K., Wankmueller, R., Anderl, M., Poupa, S., and Wieser, M.: Inventory Review 2009. Emission Data reported under the LRTAP Convention and NEC Directive. Stage 1 and 2 review. Status of gridded data and LPS data. EMEP/CEIP Technical Report 1/2009, Umweltbundesamt GmbH, Vienna, Austria, 2009.

Norsk Standard: Norwegian Standard for Enclosed wood heaters; NS 3058-2; available at: http://www.standard.no/en/, 1994.

Onasch, T. B., Trimborn, A., Fortner, E. C., Jayne, J. T., Kok, G. L., Williams, L. R., Davidovits, P., and Worsnop, D. R.: Soot Particle Aerosol Mass Spectrometer: Development, Validation, and Initial Application, Aerosol Sci. Tech., 46, 804-817, doi:10.1080/02786826.2012.663948, 2012.

Paton-Walsh, C., Emmons, L. K., and Wiedinmyer, C.: Australia's Black Saturday fires - Comparison of techniques for estimating emissions from vegetation fires, Atmos. Environ., 60, 262-270, doi:10.1016/j.atmosenv.2012.06.066, 2012.

Petzold, A. and Schönlinner, M.: Multi-angle absorption photometry - a new method for the measurement of aerosol light absorption and atmospheric black carbon, J. Aerosol Sci., 35, 421-441, doi:10.1016/j.jaerosci.2003.09.005, 2004.

Reis, S., Pinder, R. W., Zhang, M., Lijie, G., and Sutton, M. A.: Reactive nitrogen in atmospheric emission inventories, Atmos. Chem. Phys., 9, 7657-7677, doi:10.5194/acp-9-7657-2009, 2009.

Riemer, N., Vogel, H., and Vogel, B.: Soot aging time scales in polluted regions during day and night, Atmos Chem Phys, 4, 18851893, 10.5194/acp-4-1885-2004, 2004.

Rohr, A. C. and Wyzga, R. E.: Attributing health effects to individual particulate matter constituents, Atmos. Environ., 62, 130152, doi:10.1016/j.atmosenv.2012.07.036, 2012.

Saarnio, K., Teinilä, K., Aurela, M., Timonen, H., and Hillamo, R.: High-performance anion-exchange chromatography-mass spectrometry method for determination of levoglucosan, mannosan, and galactosan in atmospheric fine particulate matter, Anal. Bioanal. Chem., 398, 2253-2264, 2010.

Schaap, M., Denier van der Gon, H. A. C., Dentener, F. J., Visschedijk, A. J. H., Van Loon, M., ten Brink, H. M., Putaud, J.-P., Guillaume, B., Liousse, C., and Builtjes, P. J. H.: Anthropogenic black carbon and fine aerosol distribution over Europe, J. Geophys. Res., 109, D18207, doi:10.1029/2003JD004330, 2004.

Schmid, H., Laskus, L., Abraham, H. J., Baltensperger, U., Lavanchy, V., Bizjak, M., Burba, P., Cachier, H., Crow, D., Chow, J., Gnauk, T., Even, A., ten Brink, H. M., Giesen, K. P., Hitzenberger, R., Hueglin, C., Maenhaut, W., Pio, C., Carvalho, A., Putaud, J. P., Toom-Sauntry, D., and Puxbaum, H.: Results of the "carbon conference" international aerosol carbon round robin test stage I, Atmos. Environ., 35, 2111-2121, doi:10.1016/S1352-2310(00)00493-3, 2001.

Simpson, D., Butterbach-Bahl, K., Fagerli, H., Kesik, M., Skiba, U., and Tang, S.: Deposition and emissions of reactive nitrogen over European forests: A modelling study, Atmos. Environ., 40, 5712-5726, doi:10.1016/j.atmosenv.2006.04.063, 2006.

Simpson, D., Yttri, K. E., Klimont, Z., Kupiainen, K., Caseiro, A., Gelencsér, A., Pio, C., Puxbaum, H., and Legrand, M.: Modeling carbonaceous aerosol over Europe: Analysis of the CARBOSOL and EMEP EC/OC campaigns, J. Geophys. Res., 112, D23S14, doi:10.1029/2006JD008158, 2007.
Simpson, D., Benedictow, A., Berge, H., Bergström, R., Emberson, L. D., Fagerli, H., Flechard, C. R., Hayman, G. D., Gauss, M., Jonson, J. E., Jenkin, M. E., Nyíri, A., Richter, C., Semeena, V. S., Tsyro, S., Tuovinen, J.-P., Valdebenito, Á., and Wind, P.: The EMEP MSC-W chemical transport model - technical description, Atmos. Chem. Phys., 12, 7825-7865, doi:10.5194/acp-127825-2012, 2012.

Skeie, R. B., Berntsen, T., Myhre, G., Pedersen, C. A., Ström, J., Gerland, S., and Ogren, J. A.: Black carbon in the atmosphere and snow, from pre-industrial times until present, Atmos. Chem. Phys., 11, 6809-6836, doi:10.5194/acp-11-6809-2011, 2011.

Sofiev, M., Vankevich, R., Lotjonen, M., Prank, M., Petukhov, V., Ermakova, T., Koskinen, J., and Kukkonen, J.: An operational system for the assimilation of the satellite information on wildland fires for the needs of air quality modelling and forecasting, Atmos. Chem. Phys., 9, 6833-6847, doi:10.5194/acp-9-68332009, 2009.

Sørensen, M., Daneshvar, B., Hansen, M., Dragsted, L. O., Hertel, O., Knudsen, L., and Loft, S.: Personal PM2.5 Exposure and Markers of Oxidative Stress in Blood, Environ Health Persp., 111, 161-165, 2003.

Spindler, G., Müller, K., Brüggemann, E., Gnauk, T., and Herrmann, H.: Long-term size-segregated characterization of PM10, PM2.5, and PM1 at the IfT research station Melpitz downwind of Leipzig (Germany) using high and lowvolume filter samplers, Atmos. Environ., 38, 5333-5347, doi:10.1016/j.atmosenv.2003.12.047, 2004.

Spindler, G., Gnauk, T., Grüner, A., Iinuma, Y., Müller, K., Scheinhardt, S., and Herrmann, H.: Size-segregated characterization of $\mathrm{PM}_{10}$ at the EMEP site Melpitz (Germany) using a fivestage impactor: a six year study, J. Atmos. Chem., 69, 127-157, doi:10.1007/s10874-012-9233-6, 2012.

Stephens, M., Turner, N., and Sandberg, J.: Particle identification by laser-induced incandescence in a solid-state laser cavity, Appl. Opt., 42, 3726-3736, 2003.

Stern, R., Builtjes, P., Schaap, M., Timmermans, R., Vautard, R., Hodzic, A., Memmesheimer, M., Feldmann, H., Renner, E., Wolke, R., and Kerschbaumer, A.: A model inter-comparison study focussing on episodes with elevated PM10 concentrations, Atmos. Environ., 42 4567-4588, doi:10.1016/j.atmosenv.2008.01.068, 2008.

Sternhufvud, C., Karvosenoja, N., Illerup, J., Kindbom, K., Lükewille, A., Johansson, M., and Jensen, D.: Particulate matter emissions and abatement options in residential wood burning in the Nordic Countries, ANP 2004:735, Nordic Council of Ministers, available at: http://www.norden.org/en/publications/ publikationer/2004-735/at_download/publicationfile, Copenhagen. 2004.

Stohl, A., Berg, T., Burkhart, J. F., Fjæraa, A. M., Forster, C., Herber, A., Hov, Ø., Lunder, C., McMillan, W. W., Oltmans, S., Shiobara, M., Simpson, D., Solberg, S., Stebel, K., Ström, J., Tørseth, K., Treffeisen, R., Virkkunen, K., and Yttri, K. E.: Arctic smoke - record high air pollution levels in the European Arctic due to agricultural fires in Eastern Europe in spring 2006, Atmos. Chem. Phys., 7, 511-534, doi:10.5194/acp-7-511-2007, 2007.

Szidat, S., Ruff, M., Perron, N., Wacker, L., Synal, H.-A., Hallquist, M., Shannigrahi, A. S., Yttri, K. E., Dye, C., and Simpson, D.: Fossil and non-fossil sources of organic carbon (OC) and elemental carbon (EC) in Göteborg, Sweden, Atmos. Chem. Phys., 
9, 1521-1535, doi:10.5194/acp-9-1521-2009, 2009.

Tarrasón, L., Fagerli, H., Gauss, M., Nyíri, A., Simpson, D., Tsyro, S., and Aas, W.: $\mathrm{S}, \mathrm{N}$ and $\mathrm{O}_{3}$ in EECCA countries, in: Transboundary Acidification, Eutrophication and Ground Level Ozone in Europe in 2006, EMEP status report, 1/2008, 67-86, The Norwegian Meteorological Institute, Oslo, Norway, 2008.

ten Brink, H., Maenhaut, W., Hitzenberger, R., Gnauk, T., Spindler, G., Even, A., Chi, X. G., Bauer, H., Puxbaum, H., Putaud, J. P., Tursic, J., and Berner, A.: INTERCOMP2000: the comparability of methods in use in Europe for measuring the carbon content of aerosol, Atmos. Environ., 38, 6507-6519, doi:10.1016/j.atmosenv.2004.08.027, 2004.

Tritscher, T., Jurányi, Z., Martin, M., Chirico, R., Gysel, M., Heringa, M. F., DeCarlo, P. F., Sierau, B., Prévôt, A. S. H., Weingartner, E., and Baltensperger, U.: Changes of hygroscopicity and morphology during ageing of diesel soot, Environ. Res. Lett., 6, 034026, doi:10.1088/1748-9326/6/3/034026, 2011.

Tsyro, S., Simpson, D., Tarrasón, L., Klimont, Z., Kupiainen, K., Pio, C., and Yttri, K. E.: Modeling of elemental carbon over Europe, J. Geophys. Res., 112, D23S19, doi:10.1029/2006jd008164, 2007.

VDI2465-2: Measurement of soot (Ambient Air) - Thermographical determination of elemental carbon after thermal desorption of organic carbon, Technical Division Environmental Measurement Technologies, VDI 2465/2, in: VDI/DIN manual Air Pollution Pre-vention Volume 4: Analysis and Measurement Methods, Beuth, Germany, 1999.

Weingartner, E., Burtscher, H., and Baltensperger, U.: Hygroscopic properties of carbon and diesel soot particles, Atmos. Environ., 31, 2311-2327, doi:10.1016/s1352-2310(97)00023-x, 1997.

Weingartner, E., Saathoff, H., Schnaiter, M., Streit, N., Bitnar, B., and Baltensperger, U.: Absorption of light by soot particles: determination of the absorption coefficient by means of aethalometers, J. Aerosol Sci., 34, 1445-1463, doi:10.1016/S00218502(03)00359-8, 2003.

Wiedinmyer, C., Quayle, B., Geron, C., Belote, A., McKenzie, D., Zhang, X., O'Neill, S., and Klos Wynne, K.: Estimating emissions from fires in North America for air quality modeling, Atmos. Environ., 40, 3419-3432, doi:10.1016/j.atmosenv.2006.02.010, 2006.
Wiedinmyer, C., Akagi, S. K., Yokelson, R. J., Emmons, L. K., AlSaadi, J. A., Orlando, J. J., and Soja, A. J.: The Fire INventory from NCAR (FINN): a high resolution global model to estimate the emissions from open burning, Geosci. Model Dev., 4, 625641, doi:10.5194/gmd-4-625-2011, 2011.

Vignati, E., Karl, M., Krol, M., Wilson, J., Stier, P., and Cavalli, F.: Sources of uncertainties in modelling black carbon at the global scale, Atmos. Chem. Phys., 10, 2595-2611, doi:10.5194/acp-102595-2010, 2010.

Visschedijk, A., Denier van der Gon, H., Droge, R., and van der Brugh, H.: A European high resolution and size-differentiated emission inventory for elemental and organic carbon for the year 2005, TNO-034-UT-2009-00688_PT-ML, TNO, Utrecht, the Netherlands, 2009.

Yttri, K. E., Aas, W., Bjerke, A., Cape, J. N., Cavalli, F., Ceburnis, D., Dye, C., Emblico, L., Facchini, M. C., Forster, C., Hanssen, J. E., Hansson, H. C., Jennings, S. G., Maenhaut, W., Putaud, J. P., and Tørseth, K.: Elemental and organic carbon in $\mathrm{PM}_{10}$ : a one year measurement campaign within the European Monitoring and Evaluation Programme EMEP, Atmos. Chem. Phys., 7, 5711-5725, doi:10.5194/acp-7-5711-2007, 2007.

Yttri, K. E., Aas, W., Tørseth, K., Fiebig1, M., Fjæraa1, A. M., Tsyro, S., Simpson, D., Bergström, R., Marečková, K., Wankmüller, R., Klimont, Z., Borken-Kleefeld, J., Cavalli, F., Putaud, J.-P., Schultz, M., Querol, X., Alastuey, A., Amato, F., Cusack, M., Reche, C., Karanasiou, A., Viana, M., Moreno, T., Pey, J., Pérez, N., Laj, P., and Wiedensohler, A.: Transboundary particulate matter in Europe, EMEP status report, 4/2011, Norwegian Institute for Air Research, Kjeller, Norway, 2011a.

Yttri, K. E., Simpson, D., Stenström, K., Puxbaum, H., and Svendby, T.: Source apportionment of the carbonaceous aerosol in Norway - quantitative estimates based on ${ }^{14} \mathrm{C}$, thermal-optical and organic tracer analysis, Atmos. Chem. Phys., 11, 9375-9394, doi:10.5194/acp-11-9375-2011, $2011 \mathrm{~b}$. 